\title{
The livelihood impacts of cash transfers in sub-Saharan Africa: beneficiary perspectives from six countries
}

Article

Accepted Version

Creative Commons: Attribution-Noncommercial-No Derivative Works 4.0

Fisher, E., Attah, R., Barca, V., O'Brien, C., Brook, S., Holland, J., Kardan, A., Pavanello, S. and Pozarny, P. (2017) The livelihood impacts of cash transfers in sub-Saharan Africa: beneficiary perspectives from six countries. World Development, 99. pp. 299-319. ISSN 0305-750X doi: https://doi.org/10.1016/j.worlddev.2017.05.020 Available at https://centaur.reading.ac.uk/68625/

It is advisable to refer to the publisher's version if you intend to cite from the work. See Guidance on citing.

To link to this article DOI: http://dx.doi.org/10.1016/j.worlddev.2017.05.020

Publisher: Elsevier

All outputs in CentAUR are protected by Intellectual Property Rights law, including copyright law. Copyright and IPR is retained by the creators or other copyright holders. Terms and conditions for use of this material are defined in the End User Agreement. 


\section{CentAUR}

Central Archive at the University of Reading

Reading's research outputs online 


\section{The Livelihood Impacts of Cash Transfers in Sub-Saharan Africa: Beneficiary Perspectives from Six Countries}

\section{INTRODUCTION ${ }^{1}$}

"I am now using my energy on my field because I can now afford fertiliser." Male beneficiary, Zimbabwe Harmonised Social Cash Transfer programme, Ward 21, Goromonzi District.

"Some of the beneficiaries have started small businesses. They have put up temporary tables where they sell sweets, biscuits, matches. Others also fry koshe and kulikuli and they sell them in the market on the road."

Female beneficiary, Ghana Livelihood Empowerment Against Poverty programme, Tali community, Tolon Gumbugu District.

"I used to be a slave to ganyu...[casual labour] ...but now I am a bit free."

Female beneficiary, Malawi Social Cash Transfer programme, Mankhanamba Traditional Authority, Phalombe District.

"God has provided me with a cushion for my aching backside and a chance in life for my grandchildren."

Female beneficiary, Kenya Cash Transfers' to Orphans and Vulnerable Children programme, Mbee Sub-Location, Kangundo District

The lives and livelihoods of poor and vulnerable people in sub-Saharan Africa (hereafter Africa) are characterised by shocks, stresses and uncertainty. In a region where poverty, chronic food insecurity 
and the HIV/AIDS epidemic contribute to significant vulnerability, shocks such as illness, death or crop failure can have profoundly negative consequences for families and individuals. Against this background, cash transfers (CTs), when functioning correctly, are a regular non-contributory sum of money given to vulnerable social groups and households (e.g. the elderly, orphans and vulnerable children [OVC], ultra-poor, labour constrained, ${ }^{2}$ and disabled) to strengthen resilience to shocks and to promote human development.

When existing flows of money entering a household are limited and precarious, CTs can smooth consumption by sustaining spending on food, education and healthcare, while preventing deleterious coping strategies (Arnold, Conway, \& Greenslade, 2011). As the quotes above from our empirical research suggest, CTs have potential to finance livelihood activities and influence labour decisions; they may also contribute to children's long-term economic future through investment in education. These livelihood dimensions are the focus of this article. Based on a cross-case analysis of data from six African countries, we present beneficiary and community perspectives on the ways CTs influence strategic livelihood choices and consider how this feeds into productive investment, social risk management and economic collaboration, taking into account factors that mediate livelihood outcomes.

The participatory orientation of our methodology places value on understanding the realities of CTs within the lived experiences of beneficiaries and those around them. As Robert Chambers (1983, 1997) has long reminded us, there is intrinsic importance in hearing the voices of poor people to understand how development interventions affect them. In a CT field dominated by large-scale quantitative impact evaluation and a paucity of qualitative studies documenting peoples' own perspectives, participatory studies have a role to play in capturing beneficiary experiences to improve programme design in ways that value the priorities of the poor. This can provide nuance to emerging 
evidence on the productive impacts of African CT programmes and give additional insight, particularly regarding how positive impact of the CT on 'intangible' dimensions of deprivation - such as lack of dignity and experiences of social exclusion - contribute to beneficiaries' ability to make more strategic livelihood choices for themselves and their children. Emphasis on lived experience also helps to capture context-specific reasons for the differences in CT impacts observed within and between countries and programmes (Davis et al., 2016).

Our research was conducted under the auspices of the 'From Protection to Production' (PtoP) project supported by the Food and Agricultural Organisation (FAO), the United Nations International Children's Emergency Fund (UNICEF), and the Department for International Development (DFID). This was a three year (2011-2014) multi-country initiative that worked in collaboration with national governments in Ghana, Kenya, Lesotho, Zimbabwe, Malawi, Ethiopia and Zambia to understand the economic impacts of CTs on the rural poor, aiming to provide insights into how social protection interventions can contribute to sustainable poverty reduction and economic growth at household and community levels. The project included three components: (i) qualitative research (except in Zambia); (ii) econometric analysis of evaluation data; and (iii) development of general equilibrium models. For this article, we focus exclusively on data derived from the qualitative component of the PtoP project led by Oxford Policy Management (OPM) in the country and fieldwork locations identified in Figure 1, with methodology and findings written up in country studies, a synthesis report, and a practice paper. $^{3}$ 


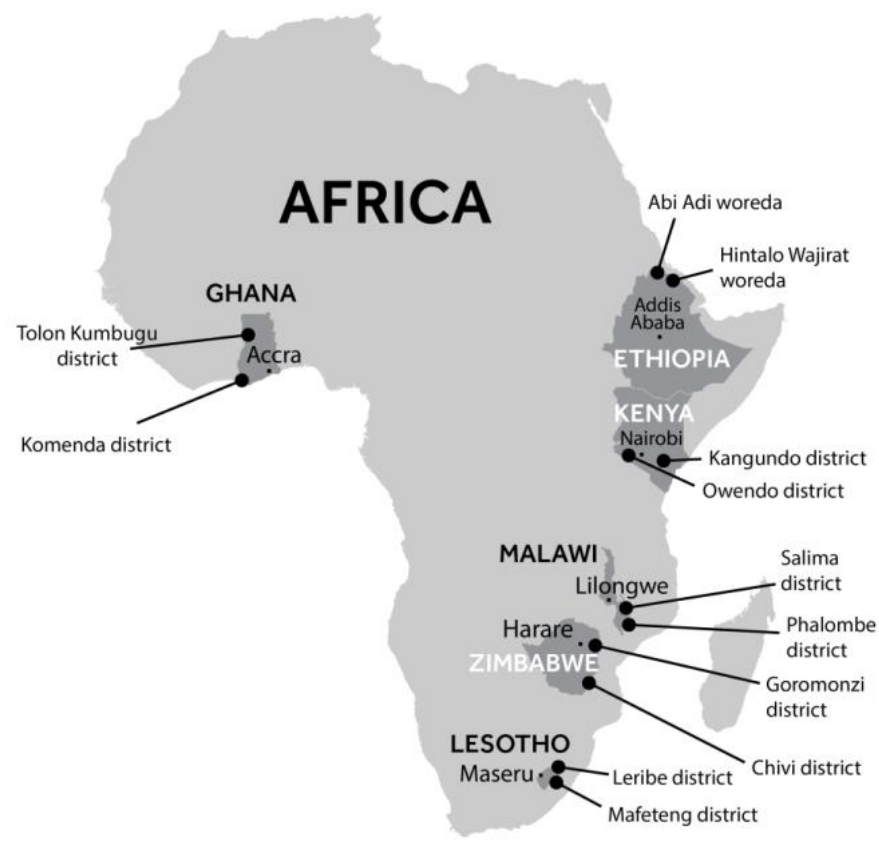

Source: Authors.

Figure 1: Fieldwork locations (country and district-level or equivalent)

The PtoP project itself was embedded within the larger, on-going 'Transfer Project', a research and learning initiative supporting improved knowledge and practice on CTs in Africa, as reported in a recent volume on the political economy of impact evaluation edited by Davis et al. (2016). Taken together, this body of work provides a new knowledge base on the role of CTs in social protection and development in Africa, generating evidence of positive social and productive impacts on beneficiary households and local economies (Davis et al., 2016b, p. 335). ${ }^{4}$

The article is structured as follows: Section two provides an overview of selected literature on the productive impact of CT programmes in Africa, elaborating on how our study builds on recent evidence. Section three puts forward a people-centred approach to livelihood impacts, informing our theory of change in terms of CT impact pathways and feeding into the methodology presented in Section four. Section five presents our findings and Section six our conclusions. 


\section{LIVELIHOOD CHANGE IN THE NEW POLITICS OF DISTRIBUTION}

For poor people living at the margins of the global economy, where land-based livelihoods and wage labour are unreliable, the distribution of CTs is a life-sustaining activity within recent models of social protection. This leads Ferguson (2015) to contend that African CT programmes are part of a new politics of distribution, in which profound shifts are at play across the Continent involving distributive transfers from government to citizens. One may debate this argument, but nevertheless the fact of new flows of cash entering chronically poor households characterised by profound vulnerability and overwhelming lack of opportunity raises crucial questions over what strategic livelihood choices people are able to make - if any - when provided with a CT and why, and how these choices are shaped by different livelihood contexts.

From early beginnings in Latin America in the 1990s, there has been exponential growth in CTs, such that by 2014 over 1 billion people around the globe received some form of transfer (World Bank, 2014, p. xiii). In keeping with worldwide trends, CT programmes have expanded rapidly in Africa: from 21 countries with at least one programme in 2010, to 37 countries in 2013 (World Bank, 2014, p. 7). Given the presence of multiple CT interventions in many African countries, there were estimated to be 123 programmes in 2012 (Garcia \& Moore, 2012, p. 3). These African programmes have regionally specific dimensions, including that they are predominantly unconditional and that targeting incorporates the concept of vulnerability alongside poverty (Davis et al., 2016a). Encompassing vulnerability implies a demographic profile for beneficiary households that typically include few working age adults and/or a high dependency ratio. These features imply the potential for wider ranging types of impact, albeit constrained by household vulnerability and labour constraint and by how the CT is targeted (e.g. on welfare and education for children), than when transfer spending is conditional on behaviour (e.g. monitored attendance at a health clinic). 
Advocates of CTs (Hanlon, Barrientos, \& Hulme, 2010) characterise them as a development revolution that challenges paternalistic thinking on poor people as irresponsible financial decision-makers. This view has its critics, notably those who question whether CTs really signal a paradigmatic shift for development, given the social reproduction of poverty within political economic structures that remain unchallenged (Ballard, 2013; see also Niño-Zarazúa, Barrientos, Hickey, \& Hulme, 2011). Nevertheless there is ample evidence that the "rise and rise of social protection" (Roelen \& Devereux, 2013, p.1) is indeed yielding significant development benefits in terms of reducing non-transient vulnerability while building human development and economic impact (e.g. Adato \& Hoddinott (eds.), 2010; Arnold et al., 2011; Barrientos, 2012; Davies et al. (eds.), 2016; Fiszbein et al., 2009). This includes positive impacts on the wellbeing of children and improved educational outcomes, with potential for long-term contribution to economic development and poverty reduction.

Against this background, we turn to evidence of the impact of CTs on livelihoods and productive investment within households and local economies in Africa. Evidence from quantitative impact evaluations on CT programmes in Zambia (Daidone et al., 2014b), Malawi (Boone, Covarrubias, Davis \& Winters, 2013; Covarrubias, Davis, Winters, 2012), Kenya (Asfaw, Davies, Dewbe, Handa \& Winters, 2014) and Lesotho (Daidone, Davis, Dewbre, Covarrubias, 2014a) reveal how alleviation of credit, liquidity and savings constraints help boost agricultural and livestock production through investment in seeds, livestock, agricultural implements and fertilizer, although there is significant variation within and between countries. Findings from Ethiopia similarly capture how beneficiaries are more likely to use improved agricultural technologies (Gilligan, Hoddinott, \& Taffesse, 2008).

Studies also document how CTs facilitate greater choice in household labour allocation decisions, although the impact of the CT varies by age, gender and location. For example, impact evaluations 
document how CTs influence the reallocation of labour from casual waged work to beneficiaries' own smallholdings (Asfaw et al., 2014; Davis et al., 2016b). Change includes reduction in child labour, both for programmes targeting OVC, e.g. in Kenya and Lesotho (Bosworth et al., 2016; Pellerano et al., 2016), and broader-based programmes targeting the ultra-poor, e.g. in Malawi (Miller, Tsoka, Reichart, \& Hussaini, 2010; Miller \& Tsoka, 2012). In addition to investment in own-farm production, CTs have been found to boost investment in income-generating activities, notably in Zambia (Daidone et al., 2014b) and for women in Kenya (Asfaw et al., 2014), but also in Malawi and Lesotho (Boone, et al., 2013; Daidone et al., 2014a). Furthermore, CTs may increase employment in prime-aged adults by facilitating labour migration e.g. in South Africa (Ardington, Case, \& Hosegood, 2009), however the relationship to migration varies by location e.g. in Malawi it is not an option for ultra-poor beneficiaries because even with CT receipt they cannot afford to migrate (Fisher et al., 2016).

An important function of many African CT programmes targeted at chronically poor, labour constrained households or OVC is investment in children's education to build long-term human capital development and break the inter-generational cycle of poverty. For beneficiaries, using the CT for school costs may be an important livelihood choice in terms of investing in their children's economic future. Evidence from both conditional and unconditional CT programmes around the world supports the view that they are effective at improving school participation (Baird et al., 2013). Emerging evidence from unconditional programmes in Africa finds significant positive impact on aspects of children's education (Bosworth et al., 2016; Pearson et al., 2016; Pellerano et al., 2016; Seidenfeld et al., 2016). Evidence appears limited, however, on the outcomes of this investment for employment and labour force participation. Partly this is due to how recent are many programmes and one expects this data to emerge. A recent study on social protection in Malawi and Decent Rural Employment (Fisher et al., 2016) emphasised the structural barriers that exist for beneficiary youth employment, skills training, and access to tertiary education. Evidence on labour market outcomes for youth beneficiaries 
of conditional CTs in Mexico (Rodríguez-Oreggia \& Freije, 2012) highlights very little evidence of impact on employment outcomes. For African CT programmes, evidence of human capital development on inter-generational occupational mobility will be an issue for future longitudinal impact analysis.

Beyond the household level, CTs are demonstrated to have wider impact, being found to boost local economies in Ethiopia, Ghana, Zimbabwe, Lesotho and Malawi, primarily through income multipliers from the raised purchasing power of recipient households (e.g. Davies \& Davey, 2008; Kagin, Taylor, Alfani, \& Davis, 2014; Thome et al., 2014; Thome et al., 2015). For example, according to Taylor, Thome and Filipski (2016), the Ghanaian Livelihood Empowerment Against Poverty programme (LEAP) may increase local income by 2.5 cedis (US\$ 0.57) for every 2 cedis (US\$ 0.46) transferred to beneficiary households. This research suggests that non-beneficiaries of CT programmes benefit through local trade and services.

From this literature, there is clear evidence that CTs can have a positive impact on production in beneficiary households and on wider local economies in Africa. There are, however, gaps in this knowledge base and here we identify three:

First, regarding the methodological approach to livelihood impacts. As highlighted in the introduction, there is limited published social research that gives expression to beneficiary and community perspectives on whether and how CTs introduce livelihoods change for programmes in Africa. There are studies that encompass data derived from qualitative methods. However, the primary focus of these studies is not on people's perspectives of the livelihood impacts of CTs. Examples of these studies include Robertson et al.'s (2013) research on community involvement in the targeting of OVC CT programmes in Zimbabwe, which used a mixed method approach incorporating a qualitative 
component on community perceptions. Also, the Overseas Development Institute's (ODI) study 'Holding Cash Transfers to Account: Beneficiary and Community Perspectives' (Samuels \& Jones, 2013), which examined psycho-social vulnerabilities, inequality and change in power dynamics between citizens and state in Uganda, Mozambique, Kenya, Yemen and Gaza and the West Bank Occupied Palestinian Territories. Finally, ethnographic research by De Sardan and colleagues that examines the local political dynamics of CT programmes in Niger (De Sardan, 2014; De Sardan, Hamani, Issaley, Adamou, \& Oumaron, I.; see also Ferguson, 2015).

A second gap is the need to understand how social dynamics shape CT livelihood impacts. The need for knowledge on a range of dimensions could be highlighted, however here we emphasise the need for better understanding of how CTs contribute to poor people's access to livelihood resources, savings mechanisms and opportunities within social networks and local communities. Existing evidence highlights the social divisiveness of CTs and issues related to elite capture of benefits (Caeyers \& Dercon, 2012; De Saardan, 2014; De Saardan et al., 2014; Ellis, 2012; MacAuslan \& Riemenschneider, 2011; Robertson et al., 2013). This raises questions regarding what impacts CTs have on social networks for risk sharing and economic collaboration, and on social inclusion or exclusion at community-level, with the consequences for livelihood choices and risk management strategies.

A third gap is the need for better understanding of the gendered nature of the livelihood impact of CTs in Africa. Existing literature on gendered impacts is primarily on conditional CT programmes outside Africa. Given the significance of structural barriers to transforming underlying gender inequalities for households in receipt of a CT in African countries, there is a need for better understand of whether and how CTs facilitate women's economic empowerment and the implications this holds for gender relations in African country contexts (Wallace \& Chapman, 2011). 


\section{A PEOPLE-CENTRED APPROACH TO CT LIVELIHOOD IMPACTS}

Our research was designed to address these aforementioned gaps in knowledge, with gender as a cross cutting theme. To bring beneficiary and community perspectives on the livelihood impacts of SCTs to the fore, the study takes a people-centred analytical approach. This draws on participatory thinking about how people's experiences of poverty and deprivation shape livelihood choices (Chambers, 1997; Chambers \& Conway, 1991; Scoones, 2009). This approach incorporates a broad view of the resources people need to generate a livelihood, which encompasses material dimensions, such as the productive assets held by beneficiary households, but also recognises how non-material dimensions, such as dignity and social inclusion, stimulate people's capability ${ }^{5}$ as they seek to make more strategic livelihood choices, including improving their children's employment chances through education.

Capability brings to the fore the significance of social relationships for people's livelihoods because these dimensions shape peoples' ways of organising their economic activities in relation to others. To paraphrase Cornwall (2007: 29), livelihood choices are both constrained and enabled by peoples' embeddedness within a web of social relations through which they manage economic contingencies. This encompasses the social networks that may be important to risk-sharing arrangements and economic collaboration, which in turn relate to the dynamics of social inclusion and exclusion that enable or restrict poor people's capability regarding access to livelihood resources, knowledge, and decision-making processes.

In framing this approach to beneficiary livelihoods, we build on a theory of change proposed by Tirivayi, Knowles, and Davis (2013) for economic research within the PtoP project. Economic theory distinguishes between the 'separable' consumption and production decisions of utility-maximising consumption and profit-maximising production in agricultural households (Singh, Squire, \& Strauss, 1986). However, as Tirivayi et al. (2013) argue, faced with multiple market failures, households make 
decisions to ensure they have enough food, not necessarily to maximise profitability, and in these circumstances, consumption and production decisions are considered 'inseparable' and household productivity is negatively affected and livelihood outcomes constrained.

Figure 2 highlights how the $\mathrm{CT}$ as a social protection intervention enters the household with potential to stimulate livelihood impact pathways in relation to these consumption and production decisions. To elaborate, membership of beneficiary households, like others, is stratified according to features such as gender and age, with change to household composition over time. For beneficiary households', issues of disability, illness, or labour constraint due to absence of able-bodied working age adults or high dependency ratios, shape multi-dimensional vulnerabilities and curtail ability to withstand stresses and shocks emerging from the wider vulnerability context. 


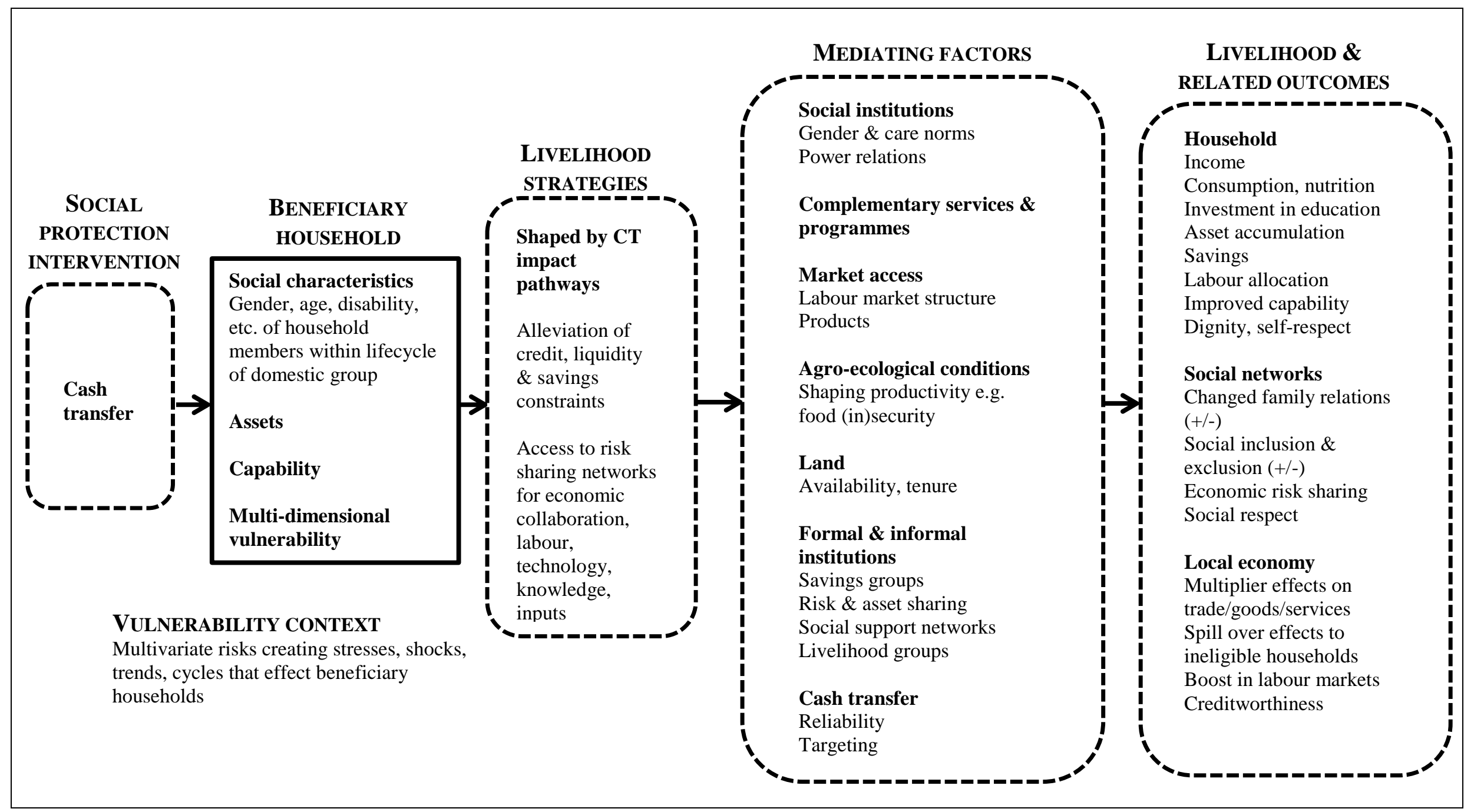

Source: Authors, drawing on Tirivayi et al. (2013).

Figure 2: Cash Transfers and Livelihood Outcomes 
Within these circumstances, a theory of change is proposed in which regular and predictable flows of cash (the CT) relax liquidity, credit and/or insurance constraints and help to improve beneficiaries' capability in making more strategic livelihood choices. This includes facilitating investment in children's education as a mechanism for breaking the inter-generational cycle of poverty and improving employability, building asset endowments and leading to change in individual and household behaviour through productive investment and labour allocation, and to local economies where CT programmes operate (data on beneficiary perceptions of local economies not included in article). Additionally, payment receipt can influence recipients' role in social networks by increasing mutually beneficial risk-sharing arrangements and economic collaboration and by greater inclusion in community-level decision-making processes that feed into livelihood strategies to generate outcomes related to productive activities and livelihood security. The realisation of impact is mediated by contextually specific factors, and by characteristics of the CT intervention itself, including its targeting, its amount relative to household size, and its reliability.

\section{METHODOLOGY}

Given current understanding of CT impact on productive activities in Africa, and taking our theory of change into account, three inter-linked hypotheses inform this research. Firstly, that the introduction of a small but predictable flow of cash income improves livelihood choices and productive investments, although vulnerable households will be more highly constrained in their decision-making on how to use the additional cash. Secondly, that CTs increase beneficial risk-sharing arrangements and economic collaboration underpinned by social capital (trust-based reciprocity). Thirdly, that changes in social networks linked to cash transfers positively affect the most vulnerable and least powerful people in a community through greater inclusion in decision-making processes (including through an increased ability to make "social contributions"), thus increasing their entitlement sets and livelihood choices. ${ }^{6}$ 
To examine the hypotheses a participatory methodology was selected whose 'emic' orientation was designed to capture peoples' perspectives on the relationship between CTs and livelihood processes within the household economy and social networks (OPM, 2012; Holland et al., forthcoming).

(a) CT programmes within the study

The study covered six CT programmes in six countries, as identified in Table 1.

\begin{tabular}{|c|c|c|c|c|c|}
\hline $\begin{array}{l}\text { Country/ } \\
\text { programme }\end{array}$ & Start $^{7}$ & Ministry & Scale* & Target group & Value \& conditionality \\
\hline $\begin{array}{l}\text { Ethiopia: Tigray } \\
\text { Social Cash Transfer } \\
\text { Pilot Programme } \\
\text { (SCTPP) }\end{array}$ & 2011 & $\begin{array}{l}\text { Tigray } \\
\text { Bureau of } \\
\text { Labour \& } \\
\text { Social } \\
\text { Affairs }\end{array}$ & 3,767 & $\begin{array}{l}\text { Labour } \\
\text { constrained, } \\
\text { ultra-poor, } \\
\text { elderly; } \\
\text { disabled } \\
\end{array}$ & $\begin{array}{l}155 \text { Ethiopian Birr (ETB) (\$US7.88)+ } \\
\text { ten per child (up to four); } 18 \text { per } \\
\text { disabled child; } 40 \text { per disabled adult; } 60 \\
\text { per elderly dependent. No conditions. }\end{array}$ \\
\hline $\begin{array}{l}\text { Ghana: Livelihood } \\
\text { Empowerment } \\
\text { Against Poverty } \\
\text { (LEAP) }\end{array}$ & 2008 & $\begin{array}{l}\text { Ministry of } \\
\text { Employment } \\
\& \text { Social } \\
\text { Welfare }\end{array}$ & 70,191 & $\begin{array}{l}\text { Elderly, } \\
\text { disabled \& } \\
\text { OVC }\end{array}$ & $\begin{array}{l}\text { Value dependent on number of } \\
\text { recipients }(\mathrm{OVC} \text {; over } 65 \mathrm{~s} \text { ): eight-15 } \\
\text { cedis (US } \$ 4.10 \text { ) per month to } \\
\text { maximum of } 15 \text { (US } \$ 7.70 \text { ) for four } \\
\text { dependents. Unconditional < } 65 \mathrm{~s} \text { and } \\
\text { disabled; OVC caregivers non- } \\
\text { monitored conditions. }\end{array}$ \\
\hline $\begin{array}{l}\text { Kenya: Cash } \\
\text { Transfer to Orphans } \\
\text { \& Vulnerable } \\
\text { Children (CT-OVC) }\end{array}$ & $2004+$ & $\begin{array}{l}\text { Ministry of } \\
\text { Gender, } \\
\text { Children \& } \\
\text { Social } \\
\text { Development }\end{array}$ & 144,637 & OVC & $\begin{array}{l}\text { Kenya Shillings } 2,000 \text { (US\$24) per } \\
\text { month, transferred bi-monthly. No } \\
\text { indexing against number of OVC. 'Soft } \\
\text { conditionality' related to education, } \\
\text { health, birth/death registration, } \\
\text { caregiver awareness raising. }\end{array}$ \\
\hline $\begin{array}{l}\text { Lesotho: Child } \\
\text { Grant Programme } \\
\text { (CGP) }\end{array}$ & 2009 & $\begin{array}{l}\text { Ministry of } \\
\text { Social } \\
\text { Development }\end{array}$ & 20,000 & $\mathrm{OVC}$ & $\begin{array}{l}\text { Quarterly, indexed to household size: } \\
\text { Maloti (M)360 (US\$36) to poor } \\
\text { households with 1-2 members; M600 } \\
\text { (US\$60) 3-4 members; M750 (US\$75) } \\
\text { 5+ members. No conditions. }\end{array}$ \\
\hline $\begin{array}{l}\text { Malawi: Social Cash } \\
\text { Transfer (SCT) }\end{array}$ & 2006 & $\begin{array}{l}\text { Ministry of } \\
\text { Gender, } \\
\text { Children \& } \\
\text { Social } \\
\text { Development }\end{array}$ & 24,300 & $\begin{array}{l}\text { Ultra-poor, } \\
\text { labour } \\
\text { constrained } \\
\text { households }\end{array}$ & $\begin{array}{l}\text { Malawi Kwacha (MK) } 1000-2400 \\
\text { (US\$2-5.50) per month (transferred bi- } \\
\text { monthly), the latter for households with } \\
\text { four members or more; 'child education } \\
\text { bonus' MK300 (US\$0.70) per month } \\
\text { per child (primary) MK600 (US\$1.40) } \\
\text { (secondary). }\end{array}$ \\
\hline $\begin{array}{l}\text { Zimbabwe: } \\
\text { Harmonised Social } \\
\text { Cash Transfer } \\
\text { Programme } \\
\text { (HSCTP) }\end{array}$ & 2011 & $\begin{array}{l}\text { Ministry of } \\
\text { Labour \& } \\
\text { Social } \\
\text { Services }\end{array}$ & 18,637 & $\begin{array}{l}\text { Ultra-poor, } \\
\text { labour } \\
\text { constrained }\end{array}$ & $\begin{array}{l}\text { Indexed by household: } 1 \text { person - US\$ } \\
10 ; 2 \text { person US } \$ 15 ; 3 \text { person US\$ } 20 \text {; } \\
\text { 4+ person US } \$ 25 \text { (bi-monthly } \\
\text { transfer). Unconditional. }\end{array}$ \\
\hline
\end{tabular}

* Approximate number of households at time of case studies.

Table 1: CT Programmes in the study 
Regarding the rationale for programme selection, this research, like the PtP project as a whole, was embedded within wider on-going support from FAO, DFID, UNICEF and partner organisations to African governments. As Davis et al. (2016a) explain, this enables evidence to be brought to bear on policy decisions and learning. By implication, the CT programmes were pre-selected on the basis of programmatic priorities and longitudinal data availability, rather than through deliberative stratification and sampling. One consequence is that the CT programmes cover different target groups: for the Kenya CT-OVC and Lesotho CGP these are poor households with OVC, for the Ethiopia SCTPP, Zimbabwe HSCT and Malawi SCTP these are ultra-poor households that are labour constrained, and for the Ghana LEAP, ultra-poor households with elderly, disabled or OVC members. This has implications for comparison across programmes, which are taken into account within our findings as part of a cross-case analysis that recognises contextual differences in CT modalities, characteristics of target beneficiary households, livelihood systems and other mediating factors (see Figure 2). ${ }^{8}$

\section{(b) Sampling strategy}

For each selected CT programme, a four stage sampling strategy was applied that identified: (i) districts (or equivalent) where the CT programme was in operation, with stratified sampling to capture two distinct and widely prevailing livelihood regions (determined by agro-ecological zones) in each country, and a random selection of one district in each region that was typical of that region's 'average' livelihood and poverty status (determined by reference to district poverty maps) (ii) sampling wards (or equivalent) ${ }^{9}$ randomly, selecting two in each district; (iii) stratifying and sampling villages (or equivalent), first clustered according to degree of market integration (with distance to main road as proxy) then an example of each selected randomly (see Table 2). For each district (or equivalent) one comparison community without programme beneficiaries was selected from a neighbouring area with similar contextual characteristics. Once locations had been selected, the final sampling stage was: (iv) 
Stratifying and sampling participants for Focus Group Discussions (FGD) and Key Informant Interviews (KII). Where possible, FGD beneficiary participants were selected randomly from a beneficiary list and FGD non-beneficiary participants from a population census list; where not possible, key informants identified a population group from whom individuals were randomly selected through referential sampling. 


\begin{tabular}{|c|c|c|}
\hline Country & $\begin{array}{l}\text { Region/District } \\
\text { (or equivalents) }\end{array}$ & Community \\
\hline \multirow{6}{*}{ Ethiopia } & \multirow{3}{*}{$\begin{array}{r}\text { Tigray } \\
\text { Region/Hintalo } \\
\text { Wajirat Woreda }\end{array}$} & Adi Keyih Kushet (Adi Keyih Tabia) - Well connected to market \\
\hline & & Daeret Kushet (Sebebera Tabia) - Remote from market \\
\hline & & Mainy Kushet (Freeweiny Tabia) - Well connected to market (comparison) \\
\hline & \multirow{3}{*}{$\begin{array}{r}\text { Tigray Region/Abi } \\
\text { Adi Woreda }\end{array}$} & All Ketenes (Kebele 01) - Market town \\
\hline & & All Ketenes (Kebele 02) - Market town \\
\hline & & All Ketenes (Kebele 02 ) - Low beneficiary population (comparison) \\
\hline \multirow{6}{*}{ Ghana } & \multirow{3}{*}{$\begin{array}{r}\text { Northern } \\
\text { Region/Tolon } \\
\text { Kumbugu District }\end{array}$} & Tali - Well connected to market \\
\hline & & Dalung - Remote from market \\
\hline & & Kpalisogu - Well connected to market (comparison) \\
\hline & \multirow{3}{*}{$\begin{array}{r}\text { Central } \\
\text { Region/Komenda } \\
\text { District }\end{array}$} & Dompoase - Well connected to market \\
\hline & & Agona Abrim - Remote from market \\
\hline & & Dwabor - Remote from market (comparison) \\
\hline \multirow{6}{*}{ Kenya } & \multirow{3}{*}{$\begin{array}{r}\text { Nyanza } \\
\text { Province/Owendo } \\
\text { District }\end{array}$} & Kandira Luwala (North Sakwa Location) - Well connected to market \\
\hline & & Kakamasia (North Sakwa Location) - Remote from market \\
\hline & & $\begin{array}{r}\text { East Kanyamkago (West Kanyamkago Location) - Well connected to } \\
\text { market (comparison) }\end{array}$ \\
\hline & \multirow{3}{*}{$\begin{array}{l}\text { Eastern Province/ } \\
\text { Kangundo District }\end{array}$} & Ngoleni (Kathiana Location) - Well connected to market \\
\hline & & Mbee (Kathiana Location) - Remote from market \\
\hline & & Kalunga (Kathioko Location) - Well connected to market (comparison) \\
\hline \multirow{6}{*}{ Lesotho } & \multirow{3}{*}{ Mafeteng District } & Metsi-Maholo - Well connected to market \\
\hline & & Malakeng - Remote from market \\
\hline & & $\begin{array}{r}\text { Ha Fako + Ha Tebelo - Well connected to market and remote from market } \\
\text { respectively (comparisons) }\end{array}$ \\
\hline & \multirow{3}{*}{ Leribe District } & Litjotjela - Well connected to market \\
\hline & & Malaoeneng - Remote from market \\
\hline & & $\begin{array}{r}\text { Boshoela + Ha Ratulo - Well connected to market and remote from market } \\
\text { respectively (comparisons) }\end{array}$ \\
\hline \multirow{6}{*}{ Malawi } & \multirow{3}{*}{ Salima District } & Siyasiya (Khombedza TA) - Well connected to market \\
\hline & & Khonthi (Khombedza TA) - Remote from market \\
\hline & & Kambwiri Sele (Karonga TA) - Well connected to market (comparison) \\
\hline & \multirow{3}{*}{ Phalombe District } & Mankhanamba (Kaduya TA) - Well connected to market \\
\hline & & Chabuka (Kaduya TA) - Remote from market \\
\hline & & Mulelemba (Kaduya TA) - Well connected to market (comparison) \\
\hline \multirow{6}{*}{ Zimbabwe } & \multirow{3}{*}{$\begin{array}{r}\text { Masvingo } \\
\text { Province/Chivi } \\
\text { District }\end{array}$} & Ward $7-$ Well connected to market \\
\hline & & Ward 32 - Remote from market \\
\hline & & $\begin{array}{r}\text { Ward } 33 \text { (Masvingo District) - Proximity to market not known } \\
\text { (comparison) }\end{array}$ \\
\hline & \multirow{3}{*}{$\begin{array}{r}\text { Mashonaland East } \\
\text { Province } \\
\text { /Goromonzi District } \\
\end{array}$} & Ward $11-$ Well connected to market \\
\hline & & Ward 21 - Remote from market \\
\hline & & Ward 1 (Seke District) - Proximity to market not known (comparison) \\
\hline
\end{tabular}

Table 2: Summary of Sampled Communities

(c) Livelihoods in the study districts

Livelihoods in the study districts, as identified in Table 3, are overwhelmingly rural and dominated by agriculture, with Abi Adi town in Ethiopia being an exception. In general, agricultural production is 
rain-fed and characterised by climate uncertainty, low productivity and food insecurity. Three sampled

districts had better agro-ecological conditions and superior market connections reflected in more

vibrant livelihood opportunities: Owendo (Kenya), Goromonzi (Zimbabwe), and Komenda (Ghana).

More remote rural communities had less economic diversity, fewer markets, and lower demand for

goods and services. In some districts, opportunities within the non-farm economy contributed

significantly to household livelihoods: fishing in Salima (Malawi), urban income-generating activities

in Abi Adi (Ethiopia), trading in Komenda (Ghana), and remittances in Mafeteng and Leribe (Lesotho).

\begin{tabular}{|c|c|}
\hline \multirow[t]{2}{*}{ Ghana } & $\begin{array}{l}\text { Komenda District: rural, rain-fed agriculture but good agro-ecology; subsistence farming, boat-making, salt } \\
\text { mining, petty trade and services. }\end{array}$ \\
\hline & $\begin{array}{l}\text { Tolon Kumbungu District: rural, rain-fed agriculture; subsistence farming with poor productivity and high } \\
\text { food insecurity; petty trade, smock weaving, head-portering, shea-nut and groundnut oil extraction. }\end{array}$ \\
\hline \multirow[t]{2}{*}{ Ethiopia } & $\begin{array}{l}\text { Hintalo Wajirat Woreda: rural, rain-fed subsistence agriculture supplemented by animal husbandry; Adi } \\
\text { Keyih Kushet uneven rainfall/drought, poor agricultural productivity, high food insecurity; Daerete Kushet } \\
\text { farming is reliable, small urban centres for petty trade. }\end{array}$ \\
\hline & $\begin{array}{l}\text { Abi Adi Woreda: urban, trade and services; rural-urban in-migration; day labouring, skilled work, trade. } \\
\text { Residents also own rural land and generate income form share cropping. }\end{array}$ \\
\hline \multirow[t]{2}{*}{ Kenya } & $\begin{array}{l}\text { Kangundo District: rural, semi-arid, access to water constrains production; subsistence and commercial } \\
\text { agriculture - livestock, food crops, horticulture, coffee, migration to Nairobi is common. }\end{array}$ \\
\hline & $\begin{array}{l}\text { Owendo District: rural, good biogeography; subsistence and commercial agriculture -sugar-cane through } \\
\text { 'out-grower' production, livestock, sugarcane jaggery, petty trade and services. }\end{array}$ \\
\hline \multirow[t]{2}{*}{ Lesotho } & $\begin{array}{l}\text { Leribe District: rural with urban centres; subsistence agriculture and livestock-rearing, sale of wool and } \\
\text { mohair, petty trading, piecemeal and factory jobs; migration to South Africa is common. }\end{array}$ \\
\hline & Mafeteng District: similar profile to Leribe District but without factory labour. \\
\hline \multirow[t]{2}{*}{ Malawi } & $\begin{array}{l}\text { Salima District: borders Lake Malawi, near lakeshore fishing, subsistence crops, and petty business; on Rift } \\
\text { Valley Escarpment, subsistence agriculture and cash cropping of cotton, sunflowers or tobacco. }\end{array}$ \\
\hline & $\begin{array}{l}\text { Phalombe District: rural, subsistence agriculture with fishing, some commercial tobacco and sunflowers, } \\
\text { opportunities for non-farm activities are limited except for casual labour. }\end{array}$ \\
\hline \multirow[t]{2}{*}{ Zimbabwe } & $\begin{array}{l}\text { Chivi District: rural, semi-arid, high food insecurity; subsistence and commercial agriculture - groundnuts } \\
\text { and cotton, livestock, fishing, gold-panning, wild-fruit collection, and handicraft making. }\end{array}$ \\
\hline & $\begin{array}{l}\text { Garomonzi District, bordering Harare, coincides with the Highveld Prime Cereal and Cash Crop } \\
\text { Resettlement Zone, with fertile soil \& good rainfall; also the Highveld Prime Communal Zone where } \\
\text { farming is hampered by poor access to inputs, labour and infrastructure. }\end{array}$ \\
\hline
\end{tabular}

Table 3: Dominant livelihood activities in the study districts ${ }^{10}$

(d) Qualitative methods 
The qualitative methods combined secondary literature and country programme review with primary data collection. Fieldwork in each country took three weeks and employed a local field team of approximately six people per country, plus external researchers (one-three) to ensure consistency across countries (co-authors of this article). Country studies followed a standardised format guided by a field manual to ensure robust, ethical field practices and rigorous replication of methods, sampling strategy, data collection and analysis (OPM, 2012; Holland et al., forthcoming). This included: one week field team training, plus a pilot and sensitisation from a senior government representative for the respective CT programme; two weeks data collection, with dual 3-4 person teams working in parallel and each week culminating in a one-day data analysis workshop. Feedback sessions were held with communities and government officials at district and national levels to enable validation and discussion of the teams' working findings.

FGDs with gender-differentiated groups of participants - beneficiaries and non-beneficiaries - enabled a range of perspectives to be captured. KIIs with group representatives and community leaders permitted in-depth probing on relevant issues. The FGDs enabled participatory reflection and analysis around the research questions, facilitated by the use of visual tools (one - two tools per FGD). The trustworthiness of this analysis was increased by observable challenges and cross-checking between group members leading to 'cumulative representation' (Chambers, 1997, p.158-9). Table 4 identifies the methods, tools and total number of FGD/KII. In each beneficiary community, 5 FGD were conducted and approximately $6 \mathrm{KII}$; and each non-beneficiary community, 3 FGD and 0 KII; approximately 4 KII (or a group meeting) were conducted with officials in each district. 


\begin{tabular}{|c|c|c|}
\hline Method & Tool and rationale & Total number of FGD/KII \\
\hline \multirow[t]{4}{*}{ FGD } & $\begin{array}{l}\text { Social Mapping (SM) \& Community Wellbeing Analysis } \\
\text { (CWA) - to understand community perceptions of poverty } \\
\text { and vulnerability, plus targeting effectiveness. }\end{array}$ & \multirow[t]{4}{*}{$\begin{array}{l}\text { Beneficiary communities: } 125 \text { FGD } \\
\text { 'Comparison' communities: } 36 \text { FGD } \\
\text { Household case studies: } 24\end{array}$} \\
\hline & $\begin{array}{l}\text { Household Income and Expenditure Analysis (HIEA) - to } \\
\text { assess the sources, size and frequency of household income } \\
\text { and to understand the impact of the CT. }\end{array}$ & \\
\hline & $\begin{array}{l}\text { Institutional Mapping (IM) - to understand the value } \\
\text { informants attached to key institutions and how near or far } \\
\text { they are perceived to be from their lives. }\end{array}$ & \\
\hline & $\begin{array}{l}\text { Livelihoods Analysis (LA) - to understand the range and } \\
\text { value of different activities and the contribution of the CT to } \\
\text { the local economy. }\end{array}$ & \\
\hline KII & $\begin{array}{l}\text { Semi-structured discussion following thematic areas identified } \\
\text { in the field guide. }\end{array}$ & $\begin{array}{l}\text { Beneficiary communities } 144 \mathrm{KII} \\
\text { Districts: approx. } 4 \text { or group meeting } \\
\text { 'Comparison' communities: } 0\end{array}$ \\
\hline
\end{tabular}

Table 4: Qualitative methods, tools and numbers of FGD and KII

Skilled participatory facilitators led the FGD / KII in local languages, unless English was preferred by participants. Within beneficiary FGDs, individual and household profile data collected for each participant identified the range of variability within the group (e.g. based on social characteristics such as age, gender, disability and on household membership). Follow up KII with 'most typical' or with 'somewhat atypical but interesting' beneficiaries presented deeper insight and in some cases generated in-depth household case studies (presented in country reports, see Footnote three).

(e) Data recording and analysis

Data recording was consistent across each country study, with information recorded on participants when ethical consent procedures were outlined. All KIIs and FGDs were documented by taking comprehensive field-notes and recording diagrams produced by participants. For ethical reasons all (translated) quotes presented in the results are anonymised.

Data analysis involved a three-stage process based on pre-defined questions linked to the study hypotheses: first, field-based analysis, including an end-of-day field team debriefing to present, discuss 
and record emerging findings from each community and an end-of-week analysis workshop (one day) to capture and synthesise emerging results. Second, desk-based analysis for country reports. Third, to facilitate comparison of evidence between countries for this article, the pre-defined questions provided the structure for a coding system within Qualitative Data Analysis (CAQDAS) software (ATLAS.ti v.7), as identified in Table 5.

\begin{tabular}{|c|c|}
\hline Hypothesis & Topic of code, linked to sub-codes for social differentiation (gender, age, etc.) \\
\hline \multirow[t]{15}{*}{ 1.Household economy } & CT expenditure decision \\
\hline & Choice of livelihood activity \\
\hline & Assets \\
\hline & Agricultural inputs \\
\hline & Agricultural labour \\
\hline & Change of livelihood strategy \\
\hline & Child labour (sub-codes: livelihood activity \& change) \\
\hline & Child education \\
\hline & Vulnerability \\
\hline & Detrimental risk coping \\
\hline & Attitude to risk \\
\hline & Subjective wellbeing \\
\hline & Perceptions of improved capability \\
\hline & Income generating activities \\
\hline & Gender relations \\
\hline \multirow{9}{*}{$\begin{array}{l}\text { 2. Social networks \& } \\
\text { 3. Economic collaboration }\end{array}$} & Existing social networks (relevant to livelihoods) \\
\hline & Identity / status and inclusion / exclusion from network \\
\hline & Importance placed on social network by beneficiaries \\
\hline & Impact of transfer on social network \\
\hline & Effect of CT on sharing arrangements (relevant to livelihoods) \\
\hline & Trade-offs with other programme impacts \\
\hline & CT impact on in-kind transfer systems \\
\hline & CT and socio-political dynamics \\
\hline & CT and gender relations \\
\hline
\end{tabular}

Table 5: Coding topics to analyse livelihood impacts of CT programmes

\section{RESULTS}

\subsection{Impact of the CT on Livelihood Choices and Productive Investments}


To consider hypothesis one, that 'the introduction of small but predictable flow of cash income improves livelihood choices and productive investments, although vulnerable households will be more highly constrained in their decision-making on how to use the additional cash', this section focuses on beneficiary and non-beneficiary perspectives regarding the CT's influence over the household economy, taking into account impact pathways identified in our conceptual framework (Figure 2). Given its primary role for social protection, beneficiaries situated CT capacity to influence their livelihood choices in terms of its vital importance for household needs, including payments for children's schooling. Because the productive relevance of CT use was situated in relation to decisions to use the CT for household needs, we turn to these dimensions first.

Although CT values were relatively low (locally) across all six countries, it represented a significant increase in household income: FGD incorporating the HIEA Tool revealed this value typically ranged between $40-60$ percent of total income over the preceding period since transfer receipt (e.g. 1-2 months). ${ }^{11}$ For a minority of extreme-poor beneficiaries, the CT was the only income stream; also, in urban Abi Adi (Ethiopia) where own-farm production is not an option (for the poor), beneficiaries relied heavily on the CT as their main source of income. Conversely, the Kenya CT-OVC in Owendo district was notable for the number of households with significant alternative income sources. ${ }^{12}$

\section{(a) Establishing Wellbeing: From Surviving to Coping}

Evidence was clear that the CT enabled households to cope better. In both direct and indirect ways this basic needs dimension acts as the foundation to improve capability and facilitate livelihood improvement: cleanliness and dignity enabled beneficiaries to engage socially, having food to eat and better diet helped people work, destructive livelihood coping mechanisms were reduced, and sending children to school contributed to aspiration for better employment chances in future. 


\section{Building dignity and self-worth}

A repeated theme across communities in all CT programmes was that the CT conferred self-worth and a sense of hope for people living in poverty. Table 6 captures examples. Such psychological impacts are often overlooked in impact evaluations but contribute in important ways to beneficiaries' capability for making choices relevant to their livelihoods. Where poverty is shameful, no longer standing out as destitute helps beneficiaries to maintain dignity and to participate in community life and economic activities. For example in Ghana, where the LEAP is targeted at the elderly alongside the disabled and OVC, the CT reinjected daily hope, as was the case for elderly beneficiaries in other programmes; in Lesotho, where the CGP was understood by community members to be for OVC, its positive psychological aspects were experienced by children.

\begin{tabular}{|l|l|}
\hline $\begin{array}{l}\text { Country \& } \\
\text { Programme }\end{array}$ & Examples of beneficiary and non-beneficiary perspectives from FGD and KII \\
\hline $\begin{array}{l}\text { Ghana } \\
\text { LEAP }\end{array}$ & $\begin{array}{l}\text { The extreme-poor are Ohianaminami 'from here you are dying' or 'bottles' 'you scratch them and } \\
\text { nothing comes off': 'I'm a poor person so I'm of no use / The family have expelled me / When there's } \\
\text { a gathering they don't call me" - song sung by female beneficiaries in Agona Abrim, Central Region, } \\
\text { who explained how LEAP had increased their sense of self-worth and self-respect due to being better } \\
\text { clothed, fed and able to 'mingle'. }\end{array}$ \\
\hline
\end{tabular}




\begin{tabular}{|c|c|}
\hline $\begin{array}{l}\text { Ethiopia } \\
\text { SCTPP }\end{array}$ & $\begin{array}{l}\text { The extreme-poor (dika) go hungry: "when you and your children are dirty close relatives may tell you } \\
\text { directly in your face "you are dirty"! Neighbours or friends may not tell you directly but will gossip } \\
\text { behind your back. Before I was shy to speak to people, for example I would not go to bars, sit down and } \\
\text { drink tella for fear others would smell me and see that I am dirty. But I now do. I can now buy soap and } \\
\text { bath every week, I feel better" - male beneficiary, Kebele 02, Abi Adi. } \\
\text { "When we were dirty other community members would ignore us, they did not greet us, but now they } \\
\text { do" - female beneficiary, Kebele 02, Abid Adi. } \\
\text { "Now they [elderly beneficiaries] are clean; you look at their faces, and they are happy! We also feel } \\
\text { happy for them" - male non-beneficiary, Daerete, Hintalo Wajirat. }\end{array}$ \\
\hline $\begin{array}{l}\text { Kenya CT- } \\
\text { OVC }\end{array}$ & $\begin{array}{l}\text { In Kangundo, the 'really, really very poor' (ngya) suffer hunger and depend on agricultural labour, } \\
\text { begging or prostitution. Therefore, "the money has helped me a lot, a lot, it is my only source of hope!" } \\
\text { - elderly male beneficiary with sole care of seven orphans, Ngoleni Sub-location, Kangundo District. } \\
\text { In Owendo, being very poor (jomo oongego) is characterised by hunger, inability to afford healthcare, } \\
\text { schooling or clothes, social exclusion, and destructive coping strategies. }\end{array}$ \\
\hline $\begin{array}{l}\text { Lesotho } \\
\text { CGP }\end{array}$ & $\begin{array}{l}\text { "[We are told that] the children should look in a manner that shows they are taken care of" - male } \\
\text { beneficiary, Malaoaneng CC, Leribe District. } \\
\text { "The grant has brought change because the children are clean and have clothes and manage to eat three } \\
\text { meals a day" - female beneficiary, Malaoangeng CC, Leribe District. }\end{array}$ \\
\hline $\begin{array}{l}\text { Malawi } \\
\text { SCT }\end{array}$ & $\begin{array}{l}\text { The extreme-poor (vanotamburisa) are "persons who are practically nobodies': "the SCT programme } \\
\text { has transformed us and God is our witness; you would hardly recognise us dressed all in white on our } \\
\text { way to a men's guild meeting at the church" - male beneficiary, Siyasiya, Salima District. } \\
\text { "I have bought more clothes because whenever I dress shabbily people think I waste money on beer. I } \\
\text { dress neatly so they appreciate the good use to which I put the money - male beneficiary, Siyasiya, } \\
\text { Salima District. } \\
\text { "Children used to use mosquito nets, while others used hessian sacks or baling cotton for blankets, but } \\
\text { now they use proper blankets to sleep under if the truth be told" - female beneficiary, Siyasiya, Salima } \\
\text { District. }\end{array}$ \\
\hline $\begin{array}{l}\text { Zimbabwe } \\
\text { HSCTP }\end{array}$ & $\begin{array}{l}\text { A female beneficiary described how going to the market in proper clothes gives her dignity and more } \\
\text { confidence "now people come to visit me more often than before" and "now I sleep better" - Ward 11, } \\
\text { Goromonzi District. } \\
\text { "They can afford to buy uniform, soap. These children are now bathing. There is a notable change in } \\
\text { attendance and appearance" - Child Protection Committee Member, Ward 32, Goromonzi District. }\end{array}$ \\
\hline
\end{tabular}

Table 6: Accounts of better hygiene and self-worth from the CT ${ }^{13}$

\section{Preventing hunger, improving diets}

A large proportion of the CT is spent on food, particularly in 'hunger months' when own-farm food supplies are finished (i.e. for many months of the year; Abi Adi town being an exception to seasonal patterns). Table 7 captures accounts of dietary change based on more meals and a better range of staples, including greater variety (e.g. maize, salt, cooking oil, sugar, and, in Ethiopia, coffee). 


\begin{tabular}{|c|c|}
\hline $\begin{array}{l}\text { Ghana } \\
\text { LEAP }\end{array}$ & $\begin{array}{l}\text { "LEAP has allowed for improvements and changes in the diets of beneficiaries. Beneficiaries are now } \\
\text { able to cook with good magi and more fish. There is more variation of food we eat" - female beneficiary, } \\
\text { Dalung, Northern Region. } \\
\text { "Now we have more plaintain in our fufu and eat vegetables such as kontomire and garden eggs as well } \\
\text { as palm oil" - female beneficiary, Dompoase, Central Region. }\end{array}$ \\
\hline $\begin{array}{l}\text { Ethiopia } \\
\text { SCTPP }\end{array}$ & $\begin{array}{l}\text { "My children and I used to eat only once a day and sometimes we would stay without food for } \\
\text { days...thanks to the CT we now buy food and eat every day, twice" - disabled male beneficiary, Abi } \\
\text { Adi. } \\
\text { "Before the CT we would greet them [referring to SCTPP beneficiaries] and ask them 'how are you'? } \\
\text { They would stare at us and reply "what'? They were so hungry and tired they could barely hear us. But } \\
\text { these days they answer and say 'I am fine, thank God!" - male non-beneficiary, Kabele 02 Abi Adi" }\end{array}$ \\
\hline $\begin{array}{l}\text { Kenya CT- } \\
\text { OVC }\end{array}$ & $\begin{array}{l}\text { "Now families don't sleep without meals, they can eat twice a day...they used to overwork to make ends } \\
\text { meet and now they don't get exhausted" - female beneficiary, Mbee, Kagundo district. } \\
\text { "Children are neat, they are eating like the rich, children are forgetting they are orphans" - female } \\
\text { beneficiary, Kakmasia, Owendo district. } \\
\text { "When the CT is received children say 'now father has come' or 'Nairobi has called', they mean they } \\
\text { can have meat" [likening the CT to mobile transfers from a migrant father] - Beneficiary Welfare } \\
\text { Committee member, Ngoleni, Kangundo District. }\end{array}$ \\
\hline $\begin{array}{l}\text { Lesotho } \\
\text { CGP }\end{array}$ & $\begin{array}{l}\text { In a KII, Rethabile, a female beneficiary in Metsi-Maholo, Mafeteng district, described how she is now } \\
\text { able to buy a sufficient amount of food to last longer and does not have to ask her neighbours for maize } \\
\text { and needs less credit from the shops. The CT also enables her to be a member of a grocery scheme. } \\
\text { "From the beneficiaries I know it [CT] is helping them. They are able to put something on the tables for } \\
\text { a few days, but it doesn't last a month" - shopkeeper, Malaoaneng CC, Leribe District. } \\
\text { Thabo, age 13: Kese ke khona ho ja ke khore. Bepheto bo hantle [my life is fine because I can now afford } \\
\text { to eat and my stomach is full]. Thabo described how now friends have also started to come with him } \\
\text { home after school because they can get something to eat in is house while before his mother would have } \\
\text { to ask neighbours to borrow maize - beneficiary, Litjotjela CC, Leribe District }\end{array}$ \\
\hline $\begin{array}{l}\text { Malawi } \\
\text { SCT }\end{array}$ & $\begin{array}{l}\text { "Food plays the starring role" - male respondent, Mulelemba, Phalombe district. } \\
\text { "We buy the chicken cuts from time to time when we get money. We buy it when there is a strong } \\
\text { craving and when we haven't had it for a long time" - male beneficiary, Ward 11, Garomonzi district. }\end{array}$ \\
\hline $\begin{array}{l}\text { Zimbabwe } \\
\text { HSCTP }\end{array}$ & $\begin{array}{l}\text { "We can now afford to have two meals per day, in the morning and in the evening" - female beneficiary, } \\
\text { Ward 7, Chivi District. } \\
\text { "Before the CT I used to buy one bucket of maize }[20 \mathrm{~kg}] \text { and now I'm able to buy } 50 \mathrm{~kg} \text { for } \$ 12 \text { " - male } \\
\text { beneficiary, Ward } 11 \text {, Goromonzi district. }\end{array}$ \\
\hline
\end{tabular}

Table 7: Perspectives on dietary change

Beyond more meals, accounts referred to improved quality and/or variety of food, however in many cases this was not sustained, being typically after CT payday. There were however examples of longer lasting dietary improvement, for example to children's nutrition identified by beneficiaries of the CTOVC in Owendo district, who use CT income for savings schemes to invest in chickens or livestock for eggs and milk. Further, improvement in variety was of note for elderly people in the Ghana LEAP.

The CT also changed purchasing patterns, enabling beneficiaries to buy greater quantities, being cheaper and helping risk-management e.g. Ghana LEAP beneficiaries in Northern Region bulk buy 
grains to eat in the 'hungry season'; similarly some HSCTP beneficiaries in Zimbabwe purchase grain as insurance against later hunger. Conversely, against the positive effects of CTs, benefits diminish in larger households, or when food prices rise, and with CT payment delays.

\section{Valuing education, long-term livelihood investment}

In keeping with quantitative data from impact evaluations across Africa (e.g. Davis et al., 2016), the research found expenditure on schooling was a priority after food, with CTs promoting school enrolment and attendance. In the long-term, investment in education contributes an important aspect to the strategic livelihood choices that beneficiary households make. As we explain in 5.1(b) below, school attendance was coupled with reduction in child labour. Absenteeism was not necessarily stopped but disruptions were fewer, and parents could negotiate school payments; meals, clothing and cleanliness also contributed to positive impact. Examples were also encountered of the difficulty of maintaining secondary school costs (Ethiopia) and ensuring transition to secondary school (Kenya).

As quotes in Table 8 suggest, the value placed on schooling was strong and consistent across all communities and programmes, not just for the OVC-targeted Kenya CT-OVC and Lesotho CGP. However, referring to these programmes specifically, it was also found that CTs can improve the voice of children in household decision-making, particularly in Lesotho, where children's rights are promoted by the Ministry of Social Development. As a female beneficiary in Leribe District explained: "children nowadays go to the legal guardian or grandmother and say I want one, two, three, etc. and the legal guardians or grandmother makes decisions along with the child".

\begin{tabular}{|l|l|}
\hline $\begin{array}{l}\text { Country \& } \\
\text { Programme }\end{array}$ & Examples of beneficiary and non-beneficiary perspectives from FGD and KII \\
\hline $\begin{array}{l}\text { Ghana } \\
\text { LEAP }\end{array}$ & $\begin{array}{l}\text { It was reported that the LEAP transfer brought about a reduction in child labour as children from } \\
\text { beneficiary households who used to work all day now worked on farms and stalls only after school } \\
\text { and on weekends. This reinforced strongly held views amongst beneficiaries and non-beneficiaries } \\
\text { that children's education was highly valued and that only under extreme distress would they put } \\
\text { their children into labour rather than into school (Doampse, Central Region). }\end{array}$ \\
\hline
\end{tabular}




\begin{tabular}{|c|c|}
\hline $\begin{array}{l}\text { Ethiopia } \\
\text { SCTPP }\end{array}$ & $\begin{array}{l}\text { "Through education children can improve their lives. One day they may even become the leaders } \\
\text { of our country!" - female beneficiary, Adi Keyih, Hintalo Wajirat. } \\
\text { "The school is as important as the mother; it takes care of children and of their development" - } \\
\text { female beneficiary, Kebele 01, Abi Adi. } \\
\text { "I am poor, I want my children capable of living a better life than me" - female beneficiary, Kebele } \\
02 \text {, Abi Adi. } \\
\text { "It [the CT] is a help, but do you think that } 35 \text { birr for [secondary] school expenses really helps us } \\
\text { to send our children to school? The sandals that they wear cost } 35 \text { birr!" - female beneficiary, Adi } \\
\text { Keyih, Hintalo Wajirat. }\end{array}$ \\
\hline & $\begin{array}{l}\text { "God has provided me with a cushion for my aching backside and a chance in life for my } \\
\text { grandchildren"- female beneficiary, Mbee Sublocation, Kangundo District. } \\
\text { A teacher in Kangundo district testified to the role of the CT for OVC children, noting that they } \\
\text { were better dressed and fed and could concentrate more than other non-CT beneficiary OVC. A } \\
\text { core objective of the CT-OVC is primary education and across all communities the value of } \\
\text { education was emphasised as a priority above productive opportunities: "some guardians use all } \\
\text { the money on business and other things. This leads to the negligence of the OVC. The community } \\
\text { rises up against this kind of guardian and usually they change". }\end{array}$ \\
\hline $\begin{array}{l}\text { Lesot } \\
\text { CGP }\end{array}$ & $\begin{array}{l}\text { "We see a lot of changes in their [beneficiaries] children because their children are now better } \\
\text { dressed and have school uniforms and they look a lot brighter [more lively]" - female non- } \\
\text { beneficiary, Litjotjela CC, Mafeteng District. } \\
\text { "There is change to the beneficiary because children have uniforms, they are clean and able to take } \\
\text { school trips, and they even have food to eat and this leads to good performance in their studies"- } \\
\text { teacher, Malakeng CC, Mafeteng District. }\end{array}$ \\
\hline $\begin{array}{l}\text { Malawi } \\
\text { SCT }\end{array}$ & $\begin{array}{l}\text { "I put the bulk of the money I get into my children's education because I want them to have a } \\
\text { bright future" - female beneficiary, Siyasiya, Salima district. } \\
\text { "An educated child becomes help in the parent's home" - female non-beneficiary, Siyasiya, } \\
\text { Salima District. }\end{array}$ \\
\hline $\begin{array}{l}\text { Zimbabwe } \\
\text { HSCTP }\end{array}$ & $\begin{array}{l}\text { "The school is important to us because they equip our children with knowledge so that they can } \\
\text { be able to look after us in the future... when there is no education there is no life" - female } \\
\text { beneficiary, Ward 7, Chivi District. } \\
\text { "I am now able to negotiate payment plan for school fees when I don't have cash" - male } \\
\text { beneficiary, Ward 11, Garamonzi District. } \\
\text { "They can afford to buy uniform, soap. These children are now bathing. There is a notable change } \\
\text { in attendance and appearance" - Child Protection Committee member, Ward 32, Chivi District. }\end{array}$ \\
\hline
\end{tabular}

Table 8: Perceptions of CT influence on children's education

(b) Building Security: Influencing Strategic Livelihood Choices

Against the background of welfare needs being the main priority for beneficiary households, we turn to consider whether the CT introduces change to the livelihood choices that beneficiaries' can make, taking into account programme, locality and social difference.

\section{Reducing destructive coping mechanisms}

The CTs generally enabled beneficiaries to reduce but not eliminate destructive coping mechanisms. Table 9 gives people's accounts of surviving prior to the CT. Strategies deployed by the poor depended 
on place, person, opportunity and desperation. They included reducing meals, selling household food, begging, school drop-out, harsh casual labour and child labour (discussed below), share-cropping out (Ethiopia and Ghana), or selling land. Strategies with negative impacts on women included early female marriage and prostitution. Other coping mechanisms were the distress sale of assets or livestock and getting into debt; here findings differed according to whether people had assets whatsoever to sell, to the cultural acceptability of 'borrowing/asking' for cash or items, and to the cultural role of livestock for risk management.

\begin{tabular}{|l|l|}
\hline $\begin{array}{l}\text { Country \& } \\
\text { Programme }\end{array}$ & Examples of beneficiary perspectives from FGD and KII \\
\hline $\begin{array}{l}\text { Ghana } \\
\text { LEAP }\end{array}$ & $\begin{array}{l}\text { "When we faced a shock we would sell our shea nuts or guinea fowl. The money was not enough, } \\
\text { imagine this... with a dying child in your arms"-female beneficiary, Tali, Tolon Kumbungu District. }\end{array}$ \\
\hline $\begin{array}{l}\text { Ethiopia } \\
\text { SCTPP }\end{array}$ & $\begin{array}{l}\text { An elderly female beneficiary in Kebele 02 (Abi Adi) recounted how she used to knock on a neighbour's } \\
\text { door, enter and wait and hope to be given food. It was not appropriate to tell her to leave so neighbours } \\
\text { would vent anger at their own children 'move, go away'! She would understand and leave: "hunger } \\
\text { pushed me to do this. Even if a barking dog guarded the house I would not be scared, I would go ahead } \\
\text { and enter, hoping to be given some food. Since I received the CT, I don't have to do this; I feel happier. } \\
\text { Before, in the street my neighbours would turn away fearing I would ask for food, now they greet me". }\end{array}$ \\
\hline $\begin{array}{l}\text { Kenya CT- } \\
\text { OVC }\end{array}$ & $\begin{array}{l}\text { "Before children were not going to school, they would keep getting chased out and would eventually get } \\
\text { discouraged...now their shoes and rags are replaced by good clothes... some houses were in bad shape } \\
\text { and others collapsing and now they are improved...they have bedding not gunny sacks...the houses are } \\
\text { clean" - female beneficiary, Mbee, Kagundo District. }\end{array}$ \\
\hline $\begin{array}{l}\text { Lesotho } \\
\text { CGP }\end{array}$ & $\begin{array}{l}\text { "Before CGP life was worse, children were not able to go to school because they didn't have proper } \\
\text { clothes or uniform"- male beneficiary, Metsi-Maholo CC, Mafeteng District. }\end{array}$ \\
\hline $\begin{array}{l}\text { Malawi } \\
\text { SCT }\end{array}$ & $\begin{array}{l}\text { An elderly widow in Khonthi (Salima District) described how she resorting to begging from neighbours } \\
\text { for money; with poor sight, she was restricted in her ability to carry out economic activities. }\end{array}$ \\
\hline $\begin{array}{l}\text { Zimbabwe } \\
\text { HSCTP }\end{array}$ & $\begin{array}{l}\text { "Before the CT I struggled to even get food, I ate rotten cabbage and the little money I got from casual } \\
\text { labour I used for food" - male beneficiary, Ward 32, Chivi District. }\end{array}$ \\
\hline
\end{tabular}

Table 9: Accounts of destructive coping mechanisms and positive CT impact

Overall, it was found the CT could help beneficiaries to adopt more positive choices, as elaborated below. However, it didn't stop households being negatively affected by shocks. When beneficiaries are extremely vulnerable because they are elderly, ill, disabled or have many dependents, then detrimental coping mechanisms readily re-emerge, either to meet daily needs or when there is a shock or crisis, including with CT payment delays. 


\section{Increasing options to withdraw from casual labour}

Distress sales of labour are vital for asset-constrained and food-insecure households. Harsh casual labour is a last resort, widely considered by communities across countries to be undesirable (although given limited opportunity and the need for money, being able to obtain casual labour was also considered important). Nevertheless, casual labour dominates the working lives of extremely poor people and being too elderly, infirm or disabled to work contributes significantly to destitution. Casual agricultural labour, specifically, also conflicts with own-farm production. Labouring work can be hard to obtain and opportunities are greatest when there is most work to be done, just at the time when households want to prepare or harvest their own land.

The research found that the CT introduces an element of strategic choice into the extent beneficiaries' participate in casual labour (see Table 10). However, it did not prevent it, and the CT needed to be dispersed regularly for positive impact to be maintained. The extent of impact varied across and within research communities, depending on household's asset endowment, vulnerability, seasonality, wider income generating opportunities, and perceived purpose of the CT (e.g. the CGP being focused on children). Positive gender differentiated impact was also noted, partly because extreme poor women with dependents are extremely dependent on casual labour and the CT enables them to do less; also because a greater number of beneficiaries are women.

Child labour can be bound to women's casual labour, especially work by younger children (rather than youth who are more independent). Beneficiaries and non-beneficiaries agreed that a major benefit of the CT was reduction in child labour. However in no community did it stop altogether - particularly in hard times, also the significant domestic burdens on male and female children remain. It was also found that although the CT may reduce what communities consider 'child labour' (i.e. paid employment outside the home), however the CT can stimulate an ambiguous shift to out-of-school work on the family farm. Malawi is typical: as result of the CT, children were reported to only take 
part in ganyu (casual labour) after school and at weekends, nevertheless "when the money ran out"14 children would do ganyu or would tend the household farm while their parents did ganyu. Beneficiaries reported being able to spend more time tending their own farms and this included children (see also

Fisher et al., 2016).

\begin{tabular}{|c|c|}
\hline $\begin{array}{l}\text { Country \& } \\
\text { Programme }\end{array}$ & Examples of beneficiary and non-beneficiary perspectives from FGD and KII \\
\hline $\begin{array}{l}\text { Ghana } \\
\text { LEAP }\end{array}$ & $\begin{array}{l}\text { "They [kaaya-yei, head-porters] think that they will get profits, but they bring losses, like a } \\
\text { pregnancy...and that adds to your burden...it's an additional mouth to feed" - male non-beneficiary, } \\
\text { Tali, Northern Region. } \\
\text { "I used to go for Kaaya-yei... .but since LEAP came, I don't go any more. My family have no source of } \\
\text { livelihood. Now with LEAP I have a source of livelihood so I don't go...if I go now...they will call me } \\
\text { a prostitute" - young female beneficiary, Tali, Northern Region. }\end{array}$ \\
\hline $\begin{array}{l}\text { Ethiopia } \\
\text { SCTPP }\end{array}$ & $\begin{array}{l}\text { In Abi Adi, the CT enabled some beneficiary women to reallocate their time from begging and searching } \\
\text { for food to casual labour (cleaning, cooking); this was perceived to be positive. }\end{array}$ \\
\hline $\begin{array}{l}\text { Kenya CT- } \\
\text { OVC }\end{array}$ & $\begin{array}{l}\text { In Mbee Sub-Location, Kangundo District, an } 80 \text { year old widow described how she looks after three } \\
\text { orphaned grandchildren, she is too old to do daily labouring but sees younger (60s) female beneficiaries } \\
\text { who are less reliant on casual labour than non-beneficiaries, but some still do a day's labour to boost } \\
\text { their income by clearing farms, feeding cows, or working in coffee factories for KSh } 150 \text { (US } \$ 1.47 \text { ) per } \\
\text { day. }\end{array}$ \\
\hline $\begin{array}{l}\text { Lesotho } \\
\text { CGP }\end{array}$ & $\begin{array}{l}\text { "For piecemeal jobs we go to people we think may be able to give them to us and sometimes they pay } \\
\text { us in kind. We decrease piecemeal jobs only around [CT] pay days, otherwise we do the same work as } \\
\text { before" - female beneficiary, Litjotjela CC, Leribe District. } \\
\text { "Some of us are able to weed and harvest even if we don't own fields and from what we get we are able } \\
\text { to support our families" - male non-beneficiary, Metsi-Maholo CC, Mafeteng District. }\end{array}$ \\
\hline $\begin{array}{l}\text { Malawi } \\
\text { SCT }\end{array}$ & $\begin{array}{l}\text { For many beneficiaries a major benefit of the CT was reducing ganyu (casual labour). Elderly or } \\
\text { chronically ill beneficiaries felt in better health as they were not exhausted by straining to do more } \\
\text { physical labour than they could cope. However not all chose, or were able, to reduce reliance on ganyu; } \\
\text { a female beneficiary in Salima District, of working age, stated that she carried out ganyu year-round and } \\
\text { would also take her children when she needed additional income. }\end{array}$ \\
\hline $\begin{array}{l}\text { Zimbabwe } \\
\text { HSCTP }\end{array}$ & $\begin{array}{l}\text { "The problem with maricho (casual labour) is that it comes at the expense of your own land but if you } \\
\text { have nothing you are forced to do maricho"- Teacher, Ward 32, Chivi District. } \\
\text { "If you don't use fertiliser and have a big family you cannot sell food and you need to find other sources } \\
\text { of income; this is why people do maricho" - village chief, Ward 11, Goromonzi District. }\end{array}$ \\
\hline
\end{tabular}

Table 10: Accounts of CT influence on casual labour

\section{JInvesting in own-farm production}

Emerging from FGD data was that farming is not only vital for food production but also fundamental to rural people's way of life "we love farming because we were raised through it and have mastered it over the years, farming is life to us". ${ }^{15}$ Therefore, for rural beneficiaries with land, own farm production was found to be the desired alternative to casual labour. ${ }^{16}$ In each country, except 
communities in Lesotho and beneficiaries living in Abi Adi town (Ethiopia), examples were given of how households had used CT income to strengthen agricultural production. This included investing greater time in farming their own land, investment in tools (hoes, sickles) inputs (fertilizer, pesticides, certified seeds), renting land (exceptionally e.g. Owendo District, Kenya), change to sharecropping arrangements, and buying livestock (Table 11). This extended to examples of the use of the CT to hire labour for beneficiary small-holdings, most commonly by the elderly or disabled beneficiaries too infirm to farm. Rural communities in Lesotho were an exception because there is strong messaging that the CT should be used for child welfare and education and this is reinforced by community norms.

\begin{tabular}{|l|l|}
\hline $\begin{array}{l}\text { Country \& } \\
\text { Programme }\end{array}$ & Examples of beneficiary and non-beneficiary perspectives from FGD and KII \\
\hline $\begin{array}{l}\text { Ghana } \\
\text { LEAP }\end{array}$ & $\begin{array}{l}\text { "In one way or the other, each of us is able to either hire an additional labourer and other farm inputs } \\
\text { such as fertiliser and chemicals" - male beneficiary in Dalung community, Tolon Kumbugu District. }\end{array}$ \\
\hline $\begin{array}{l}\text { Lesotho } \\
\text { CGP }\end{array}$ & $\begin{array}{l}\text { "The money is intended for the poor and orphans and it is for them to improve their lives. It is not right } \\
\text { to invest the money in agriculture, it is not allowed. CGP is intended for the children" - female } \\
\text { beneficiary, LItjotjela CC, Leribe District. }\end{array}$ \\
\hline $\begin{array}{l}\text { Kenya CT- } \\
\text { OVC }\end{array}$ & $\begin{array}{l}\text { Categorised as 'middle' by the CWA tool, Mary Aluko, 48, is married and a farmer. She looks after 18 } \\
\text { children and the CT "eases the burden". The family farm is 1.9 acres and grows food crops, 70 percent } \\
\text { for sale. The CT is combined with other sources of income and therefore used to buy fertilizer, pesticides, } \\
\text { top-dressing, compost and seeds. Mary invests in cows for ploughing and milking, in goats for milk, and } \\
\text { chickens for meat and eggs. Income from farm produce is helped by cereal banking, for sale when prices } \\
\text { are high. Mary is a member of three savings groups and has had a government grant of US } \$ 589 \text { for } \\
\text { Income Generating Activity (IGA) support. }\end{array}$ \\
\hline $\begin{array}{l}\text { Zimbabwe } \\
\text { HSCTP }\end{array}$ & $\begin{array}{l}\text { "I am now using my energy on my own field because I can now afford fertiliser" - male beneficiary, } \\
\text { and } 21, \text { Gore focusing more on producing for themselves in their fields since they now had enough money } \\
\text { to purchase fertilizer and maize seeds. }\end{array}$ \\
\hline
\end{tabular}

Table 11: Examples of CT influence on own-farm production

A typical case of when productive investment was feasible was that of LEAP households (Ghana), a majority of beneficiaries are too old, ill or disabled to work (in line with targeting) and therefore household expenditure focused on welfare needs. However, for a minority without these overwhelming needs, living in both Central and Northern Regions, the CT was used to hire labour, buy inputs, expand farm size, or diversify agricultural strategies e.g. by buying animals or engaging in petty business. 
Generally, and as to be expected, agricultural investment was dependent on the extent of welfare demands in beneficiary households at a given time. This included the need for money for children's schooling. While there was evidence of positive impact on production, it was nevertheless either difficult or impossible for the most vulnerable and labour constrained households to make these investments. Also there were places where poverty and vulnerability levels were exceptionally high, in which case very few cases of productive investment were found, notably Chivi District in Zimbabwe and Adi Keyih Kushet in Hitalo Wajirat, Ethiopia. Productive investment was also shaped by wider opportunity structures related to availability of land, labour and produce markets. ${ }^{17}$ Feeding into this was whether there were alternative opportunities, e.g. for petty-business, that beneficiaries preferred to invest in and again this option was strongly influenced by the dynamism of the local economy, and also seasonality.

There were gender dimensions to beneficiary choices around own-farm productive investment, which - unsurprisingly - intersected with gendered expectations of productive roles and of decision-making over household expenditure. Here the gendered impact of the CT differed significantly between contexts, reflecting cultural features and the wider economic environment and household socioeconomic status. As an illustration, in Tigray Region (Ethiopia), female headed-households confront an additional gender obstacle to their ability to farm, namely while it is culturally acceptable for women to participate in weeding and harvesting there is a cultural norm against women ploughing with oxen. In the absence of family male labour, female headed-households sharecrop their plots, with poor returns on their land. However, in Daerete Kushet it was found that with the CT women could farm alone by employing male labour. 
FGD identified a bricolage of livelihood activities through which poor people in CT communities get by, and which to varying extents augment casual labour and own farm production. These include petty business, trade, services, and collection of firewood and non-timber forest products. Activities varied, depending on opportunities present within localities, the season, gender, age, and other demands on people's time. For women in particular these demands included caring for dependents and domestic labour.

Table 12 gives examples of the non-farm livelihood activities engaged in by beneficiaries and how the CT is used. Typically, activities had low start-up costs, were low risk, and generated limited profit. Remembering that the SCTPP, the HSCTP, the SCT, and the LEAP are by design safety nets aimed at labour-constrained and food insecure households, ability to diversify is, unsurprisingly, determined by beneficiaries' welfare needs, investment in children's education, household asset endowment, and labour power. It was also strongly mediated by opportunities in the wider economy, with examples of investment being most extensive where a dynamic economy and greater access to markets stimulated a greater range of opportunities to reinforce positive livelihood choices. This was particularly in communities in Owendo (Kenya), Goromonzi (Zimbabwe), and Komenda (Ghana) districts.

When good opportunities were present, households with 'marginally better-off' beneficiaries and ablebodied adults were most able to start new income-generating activities, particularly related to highervalue and higher-risk activities. Ability to be part of micro-credit or savings institutions fed into this (Section 5.2). Conversely, diversification was limited or non-existent for the poorest beneficiaries in labour constrained households. CT messaging also influenced income-generation, either deterring (e.g. Lesotho) or encouraging (e.g. Ethiopia) investment. An important point is that even for those households that did manage to invest CT income in new activities often they were seasonal and not sustained through the year, and they were vulnerable to shocks (including late receipt of the CT). This 
suggested limited robustness in the beneficiary asset-base and the role of these activities as a coping strategy rather than a means towards greater 'entrepreneurship' or livelihood improvement based on sustained change to the household economy.

\begin{tabular}{|l|l|}
\hline $\begin{array}{l}\text { Country \& } \\
\text { Programme }\end{array}$ & Examples of beneficiary and non-beneficiary perspectives from FGD and KII \\
\hline $\begin{array}{l}\text { Ghana } \\
\text { LEAP }\end{array}$ & $\begin{array}{l}\text { A common form of increased investment from the CT amongst beneficiary households was in petty } \\
\text { trading (kerosene, household items and, notably for women, cooked food sales); with ease of entry } \\
\text { through small start-up costs but with low profit margins. Any profit was spent on immediate } \\
\text { consumption. }\end{array}$ \\
\hline $\begin{array}{l}\text { Ethiopia } \\
\text { SCTPP }\end{array}$ & $\begin{array}{l}\text { Examples of activities stimulated by the CT are: in Abi Adi, women's Tella brewing, which requires } \\
\text { minimal start-up capital and is therefore an option for the poor. E.g. an HIV+ woman said since the CT } \\
\text { she joined a rotating savings group (iqqub - see Section 5.2) and bought her own container, now selling } \\
\text { residue for 14 ETB (US\$0.71) with 34 ETB (US\$1.72 profit) - female beneficiary, Kebele 01. }\end{array}$ \\
\hline
\end{tabular}




\begin{tabular}{|c|c|}
\hline & $\begin{array}{l}\text { In contrast, a female beneficiary living in a cave dwelling over-looking Abi Adi with } 5 \text { under } 18 \mathrm{~s} \text { and an } \\
\text { elderly blind man, had heard CT-messaging about investment but the money was too little and her needs } \\
\text { are too great "I cannot work or do IGA, this is why I am not changed significantly". } \\
\text { In Daerete a small number of beneficiaries (female headed and the elderly) living close to an irrigation } \\
\text { area bought seedlings and started to grow vegetables and gesho (like hops) to sell. An elderly male } \\
\text { beneficiary was "isolating himself" "to forget hunger and poverty" by spending most of his day at the } \\
\text { church. With the CT he bought gesho seedlings and is selling produce at the Saturday market in Adi } \\
\text { Guddom. He "feels better and more confident" and socializes more often. } \\
\text { In Adi Keyih, where food insecurity and poverty are rising, beneficiaries provided no evidence of the } \\
\text { CT being used to improve productivity through farm or income generating activities rather it was a safety } \\
\text { net. }\end{array}$ \\
\hline $\begin{array}{l}\text { Kenya CT- } \\
\text { OVC }\end{array}$ & $\begin{array}{l}\text { There were differences in the capacity of households to invest in IGAs, depending on household welfare } \\
\text { needs, investment in children's education, and opportunities available in localities. In Kangundo District, } \\
\text { women (middle-aged rather than elderly) reported the CT helped petty business selling farm produce } \\
\text { and small food items. In Owendo District, with a dynamic economy and greater household investment } \\
\text { capacity (due in part to CT targeting issues resulting in inclusion errors), the CT was used for income- } \\
\text { generation, in some cases in risker higher-value activities, including petty trade, cereal banking, crop } \\
\text { sales, cooked food sales, hiring out ploughing cows. For poorer women, a common activity was the } \\
\text { "fwoka" business (Luo, to empty something from a container), when produce was spread on the ground } \\
\text { at a small market. }\end{array}$ \\
\hline $\begin{array}{l}\text { Lesotho } \\
\text { CGP }\end{array}$ & $\begin{array}{l}\text { The CT was mainly used for food consumption and meeting education-related costs, very few examples } \\
\text { were found of investment stemming from the CT. Beneficiaries said the money was not enough, it was } \\
\text { meant for children, and they were "not allowed" to invest. "They don't see any changes, they don't see } \\
\text { us invest, we are mainly concentrating on children - we are the same people, doing the same things and } \\
\text { the only change is our children" - female beneficiary, Lijotjela CC, Lerebe District. }\end{array}$ \\
\hline $\begin{array}{l}\text { Malawi } \\
\text { SCT }\end{array}$ & $\begin{array}{l}\text { Near road communities: investment in small businesses selling boiled maize, doughnuts, pancakes, and } \\
\text { brewing beer (female); selling firewood and making brooms and mats (male). } \\
\text { Remote communities: little investment in businesses, reliance on support from neighbours and relatives. } \\
\text { CT impact: greater in places with a tradition of enterprises, where inputs are available, and where there } \\
\text { are customers - i.e. greater access to markets and opportunities. }\end{array}$ \\
\hline $\begin{array}{l}\text { Zimbabwe } \\
\text { HSCTP }\end{array}$ & $\begin{array}{l}\text { While the CT has enabled beneficiary households to reduce their indebtedness and distress sale of assets, } \\
\text { and to increase food consumption etc., it generally hasn't stimulated new livelihood activities. They } \\
\text { [beneficiaries] don't make investments. They don't have the chance to invest, whenever the money } \\
\text { comes they have to pay those that they have borrowed from and with the remainder they buy food" - } \\
\text { Child Protection Committee member, Ward 32, Chivi District. Lack of investment was particularly the } \\
\text { case in Chivi District, where over } 70 \text { percent of beneficiary household heads were over 60. In relatively } \\
\text { resource rich and climatically favourable Goromonzi District, there was higher incidence of investments } \\
\text { oriented towards higher productivity and diversified livelihoods e.g. purchasing goats and broilers, } \\
\text { buying milk for resale, improving poultry production. }\end{array}$ \\
\hline
\end{tabular}

Table 12: Accounts of beneficiary involvement in non-farm livelihood activities

Transforming women's access to and control over household resources

Across countries, there was evidence that CTs could help improve women's capability, enabling them to make strategic choices, for example, influencing the reallocation of time use to different activities. However, it did not reduce the burden of women's labour overall, domestic or productive. In Kangundo District (Kenya), for example, reduction in long-hours of casual labour enabled women to spend more 
time doing housework; likewise, in Abi Adi (Ethiopia), the CT enabled female beneficiaries to reallocate time spent from begging to obtain day labouring work as cleaners or cooks.

Overall, while there was evidence to positive change to women's choices regarding livelihood activities and labour allocation, the CT did not significantly transform gendered household decisionmaking but conformed to existing norms. These norms on female decision-making varied with regard to the degree of female independence e.g. there was greater female de facto role in decision-making where there is a history of male labour migration e.g. in communities in Lesotho, Zimbabwe, and Kangundo district of Kenya. However, the CT could have the net effect of increasing women's access to and control over resources where targeting mechanisms skewed transfers towards female-headed households e.g. the LEAP in Ghana and SCT in Malawi. These cases highlighted how where women controlled income and profits, and could make decisions independently from male kin, there was a potential for increasing female empowerment. Nevertheless, there was no evidence that CTs are transforming patriarchal norms within CT communities or beneficiary households.

\subsection{Generating Beneficial Risk-Sharing Arrangements and Economic Collaboration}

Social risk sharing, economic collaboration and social inclusion may play important roles in supporting new livelihood choices and opportunities for both male and female beneficiaries. Therefore, the research examined different aspects of CT impact on social networks, based on two connected hypotheses. First, that 'CTs cash transfers increase beneficial risk-sharing arrangements and economic collaboration underpinned by social capital (trust-based reciprocity)'. And, second, 'that changes in social networks linked to cash transfers positively affect the most vulnerable and least powerful people in a community through greater inclusion in decision-making processes (including through an ability to make "social contributions") and increasing their entitlement sets and livelihood choices'. For note,

there were many differences between communities in terms of social relationships and network 
dynamics underpinned by society-specific institutions and cultural norms. This generated rich data but also highlighted specificities that cannot be generalised, we therefore bring only key findings relevant to livelihoods decision-making to the fore.

\section{(a) Relying on family and kin relations}

Feeding into a household's economic coping ability are nuclear family relations. Across countries and communities, the IM tool demonstrated that beneficiaries and non-beneficiaries consider immediate family as central for support. With the CT, beneficiaries were perceived to become less burdensome by reducing the need for financial assistance, and/or increasing their own contribution. Table 13 captures examples. In contrast, attitudes towards extended kin were often negative, although this varied according to the cultural norms shaping kinship obligations. Indeed, even where extended families were seen as a drain, the CT enabled beneficiaries to respond positively to kinship obligations, particularly related to funerals and marriages, with examples captured in Tables 13 and 14 . Furthermore, in the CT-OVC in Kenya specifically, there was evidence the CT stimulated willingness for kin to take responsibility for OVC, which was positive for children's futures.

\begin{tabular}{|l|l|}
\hline $\begin{array}{l}\text { Country \& } \\
\text { Programme }\end{array}$ & Examples of beneficiary and non-beneficiary perspectives from FGD and KII \\
\hline $\begin{array}{l}\text { Ghana } \\
\text { LEAP }\end{array}$ & $\begin{array}{l}\text { One female beneficiary in Agona Abrim, Central Region, explained how even before LEAP she would } \\
\text { still pay her family levy using family remittances. If you stopped contributing then: "if you die you will } \\
\text { be buried without a coffin". }\end{array}$ \\
\hline $\begin{array}{l}\text { Kenya CT- } \\
\text { OVC }\end{array}$ & $\begin{array}{l}\text { "When you are in trouble, they... [family]... are the first to help" - female beneficiary, Mbee Sub- } \\
\text { "[Family] ... when you have problems they are the first to help and there is a lot of communication" - } \\
\text { male beneficiary, Ngoleni Sub-Location, Kangundo District. } \\
\text { "[Relatives]... you have to consult them over decisions because it affects your kinship group; you have } \\
\text { a responsibility to your kin. They arbitrate over disputes and mediate over marriages"-male beneficiary, } \\
\text { Ngoleni Sub-Location, Kangundo District. }\end{array}$ \\
\hline
\end{tabular}




\begin{tabular}{|c|c|}
\hline $\begin{array}{l}\text { Ethiopia } \\
\text { SCTPP }\end{array}$ & $\begin{array}{l}\text { In the remote rural kushet of Daerete in Hintalo Wajirat woreda familial relations of mutal aid and } \\
\text { support to the poor were linked to a strong sense of kinship obligations. "they are our family, how can } \\
\text { we ignore them and not help" (female, non-beneficiary). In urban Abi Adi familial support appeared to } \\
\text { be weaker, particularly because relatives might live away in rural areas. "My relatives do not come to } \\
\text { visit me often when I am sick... [because they don't want the burden of bringing gifts]... But I am a } \\
\text { member of the Maylomin Iddir Society and I have told them "don't you worry about me, my iddir fellows } \\
\text { will take care of my funeral when my time comes" - HIV positive female beneficiary, Kebele 01, Abi } \\
\text { Adi. In the absence of good familial connectedness there was a strong reliance on neighbours and } \\
\text { community self-help institutions for support and risk sharing. }\end{array}$ \\
\hline $\begin{array}{l}\text { Lesotho } \\
\text { CGP }\end{array}$ & $\begin{array}{l}\text { "Family are always supportive regardless of what you do and very close to our hearts because they are } \\
\text { always eager to help and for instance they buy food when we go hungry" - female beneficiary, } \\
\text { Malaoaneng CC, Leribe District. } \\
\text { "These are the people... [immediate family]... who when I say I'm sick they are immediately here. They } \\
\text { are our beloveds" - female beneficiary, Malakeng CC, Mafeteng District. } \\
\text { "I am very happy as my father-in-law is now getting the grant which means I no longer have to support } \\
\text { his family and am no longer burdened" - female non-beneficiary, Malakeng CC, Mafeteng District. } \\
\text { "They... [relatives]... are not people you would run to in times of need; it is only immediate family that } \\
\text { helps you" - female beneficiary, Malakeng CC, Mafeteng District. } \\
\text { "Relatives are less important as they are not really available in times of need. They are the same people } \\
\text { who pull you down" - female beneficiary, Litjotjela CC, Leribe District. }\end{array}$ \\
\hline $\begin{array}{l}\text { Zimbabwe } \\
\text { HSCTP }\end{array}$ & $\begin{array}{l}\text { "Family are always supportive regardless of what you do and very close to our hearts because they are } \\
\text { always eager to help and for instance they buy us food when we go hungry" - female beneficiary, } \\
\text { Malaoaneng CC, Leribe District. } \\
\text { "Relatives are less important as they are not really available in times of need. They are the same people } \\
\text { who pull you down" - female beneficiary, Litjotjela CC, Leribe District. } \\
\text { "Relatives are destructive. They are jealous. They do not give us help when we are in real need. Friends } \\
\text { are better than relatives because friends don't get jealous, they help most and they are genuine" - female } \\
\text { beneficiary, Ward 11, Garamonzi District. }\end{array}$ \\
\hline
\end{tabular}

Table 13: Perspectives on the support of family and kin

(b) Social inclusion and entry into contribution-based social networks

As discussed in 5.1., the CT improved beneficiaries' cleanliness and dignity. There was good evidence across communities that this contributed to social inclusion, enabling social relationships to be (re)established and promoting engagement with social and economic networks in which cash or material contribution is obligatory (Table 14).

\begin{tabular}{|l|l|}
\hline $\begin{array}{l}\text { Country \& } \\
\text { Programme }\end{array}$ & Examples of beneficiary and non-beneficiary perspectives from FGD and KII \\
\hline Ghana & $\begin{array}{l}\text { "In fact it's rather embarrassing...if something [birth, wedding, or death] happens you cannot even show } \\
\text { Leur face.... what would you take there? Now when someone dies they say "come come" - beneficiary, } \\
\text { Agona Abrim. } \\
\text { "I always give a portion of the LEAP money to the aged beneficiary... [respondent's father]... so he can } \\
\text { contribute to social events such as funerals, naming ceremonies and weddings" - caregiver, Dalung, } \\
\text { Northern Region. }\end{array}$ \\
\hline $\begin{array}{l}\text { Kenya CT- } \\
\text { OVC }\end{array}$ & $\begin{array}{l}\text { When the IM tool was being conducted one group of male non-beneficiaries graphically illustrated how } \\
\text { the CT had changed beneficiary social relations by moving beneficiaries from a distant position to one } \\
\text { denoting closeness (Ngoleni Sub-Location, Kangundo District). }\end{array}$ \\
\hline
\end{tabular}




\begin{tabular}{|c|c|}
\hline $\begin{array}{l}\text { Ethiopia } \\
\text { SCTPP }\end{array}$ & $\begin{array}{l}\text { "The CT has taken a burden off our shoulders. Elders are our relatives, and we had to support them. The } \\
\text { money is not only helping beneficiaries but also the people who used to support them" - male non- } \\
\text { beneficiary, Daerete Kushet, Intalo Wajirat Woreda. } \\
\text { "Having social relations means respect and inclusion. If you don't have social relations you feel } \\
\text { neglected" - elderly male beneficiary, Daerete Kushet, Hintalo Wajirat. } \\
\text { "If I have one injera to eat for breakfast and dinner, I prefer to skip breakfast so that a poor neighbour } \\
\text { can also eat" - female beneficiary, Kebele } 02 \text {, Abi Adi. } \\
\text { Iddir societies... "As an iddir member I feel safe and I don't worry how my family will afford to give } \\
\text { me a decent burial" - female beneficiary, Kebele } 02 \text {, Abi Adi. } \\
\text { Iddir societies... "In our culture it is acceptable not to attend a wedding, but you must attend the funeral } \\
\text { of a relative, friend, colleague or neighbour. Not attending a funeral would put you in very bad terms } \\
\text { with the family" - Chairman, Maylomin Iddir Society, Kebele } 02 \text {, Abi Adi. }\end{array}$ \\
\hline $\begin{array}{l}\text { Lesotho } \\
\text { CGP }\end{array}$ & $\begin{array}{l}\text { "Community societies are very important as they help you in your greatest need such as funerals or when } \\
\text { you are in dire need of food" - female beneficiary, Malakeng CC, Mafeteng District. } \\
\text { "There are few schemes that we have in this village, but they have always been around and they did not } \\
\text { start since the introduction of the CT" [referring to a burial society with beneficiary members]. }\end{array}$ \\
\hline $\begin{array}{l}\text { Malawi } \\
\text { SCT }\end{array}$ & $\begin{array}{l}\text { "A friend is very important because you easily ask for assistance from them, like asking them to give } \\
\text { you some flour when in need"- female non-beneficiary, Siyasiya, Salima District. }\end{array}$ \\
\hline $\begin{array}{l}\text { Zimbabwe } \\
\text { HSCTP }\end{array}$ & $\begin{array}{l}\text { "We are in hard times, you cannot just lend" - Child Protection Committee member, Ward 32, Chivi } \\
\text { District. } \\
\text { "We help each other... [beneficiaries and non-beneficiaries]... in whatever way we can when we also } \\
\text { have food to spare. Now they are in a position to share since they have begun receiving CTs" - female } \\
\text { non-beneficiaries, Ward 7, Chivi District. } \\
\text { "They now see us as real people with worth" - beneficiary, Ward 21, Goromonzi District. } \\
\text { "According to our custom everyone support the poor and makes contributions for their funeral. If it were } \\
\text { not for this custom you would not see these rich people contributing" - Child Protection Committee } \\
\text { member, Ward 32, Chivi District. }\end{array}$ \\
\hline
\end{tabular}

Table 14: Perspectives of CT contribution-based networks and social relations

Even where evidence was positive regarding the CT facilitating greater social inclusion, being a CT beneficiary could nevertheless stimulate social rifts, particularly through jealousy from 'nearlybeneficiaries' in communities where poverty levels are high and there is a greater sense of entitlement. Table 15 highlights examples. These rifts were generally long-term resentments with shorter-lived flare-ups during targeting or around payment days. There was some variation according to cultural norms of support for the poor (e.g. jealousy although present was less an issue in Ethiopia) and to limited community understanding of targeting and beneficiary selection, findings that confirm wider research. ${ }^{18}$ It is also worth noting that ill will was not always directed at beneficiaries, but at community committees, local authorities or those perceived to have decision-making power. 


\begin{tabular}{|l|l|}
\hline $\begin{array}{l}\text { Country \& } \\
\text { Programme }\end{array}$ & Examples of beneficiary and non-beneficiary perspectives from FGD and KII \\
\hline Ghana & $\begin{array}{l}\text { In Dalung, Northern Region, both beneficiaries and non-beneficiaries complained that targeting had } \\
\text { created underlying tension. "Nearly" beneficiaries complained about not receiving the transfer and } \\
\text { beneficiaries "worried" that because others were not getting the transfer resentments and problems had } \\
\text { been created. } \\
\text { In Dompoase, Central Region, there were examples of 'self-selection' off the list because non- } \\
\text { beneficiaries linked the early round of LEAP targeting to the popular sakawa notion of fraud. }\end{array}$ \\
\hline $\begin{array}{l}\text { Kenya CT- } \\
\text { OVC }\end{array}$ & $\begin{array}{l}\text { "Why do you ask me for salt or a matchbox, why? Yet you are okay, you laugh at me, you laugh at my } \\
\text { plight, stop insulting me just because you get the CT and I don't" - female non-beneficiary, Kakmasia } \\
\text { Sub-location, Owendo District. }\end{array}$ \\
\hline
\end{tabular}




\begin{tabular}{|c|c|}
\hline & $\begin{array}{l}\text { "Before we were the same, now they walk differently" - female non-beneficiary, Kakmasia Sub- } \\
\text { location, Owendo District. }\end{array}$ \\
\hline $\begin{array}{l}\text { Ethiopia } \\
\text { SCTPP }\end{array}$ & $\begin{array}{l}\text { In both rural Hintalo Wajirat and urban Abi Adi non-beneficiaries frequently expressed appreciation for } \\
\text { the CT, perceiving it as an important support for vulnerable beneficiaries who in their opinion deserved } \\
\text { to be assisted: } \\
\text { "We feel sorry for them, they cannot even afford clothes or shoes, we are happy for this support" } \\
\text { female non-beneficiary, Kebele } 01 \text {, Abi Adi. } \\
\text { "The rich can now eat in private" - female non-beneficiary referring to not having neighbours begging, } \\
\text { Kebele 01, Abi Adi. } \\
\text { There were some examples of jealousy in Abi Adi although not Hintalo Wajirat: "Arent you a } \\
\text { beneficiary? You go and clean the streets, we have work to do" - female beneficiary describing jealousy, } \\
\text { Kebele 02, Abi Adi. }\end{array}$ \\
\hline $\begin{array}{l}\text { LESOTHO } \\
\text { CGP }\end{array}$ & $\begin{array}{l}\text { "We are very sad. Our hearts are broken by our exclusion because we also care for orphans" - male non- } \\
\text { beneficiary, Malekeng CC, Mafeteng District. } \\
\text { "Our relations with our neighbours are still the same but we become jealous when we see their children } \\
\text { wearing new shoes or clothes because we believe that we are just as poor and deserve the money"- } \\
\text { female non-beneficiary Metsi Maholo CC, Mafeteng District. } \\
\text { "Relationships are still the same but people 'just talk'. It is the women who hold more grudges as they } \\
\text { feel they also have children and should also be receiving it. It generally affects women's relationships. } \\
\text { Around pay day they just pass you without greeting you and a few days later they start talking to you } \\
\text { and mockingly say 'you have eaten well"" - male beneficiary, Malaoaneng CC, Leribe District. } \\
\text { Non-beneficiaries do not talk to us. They even mock us saying nice food, delicious food, when we cook } \\
\text { something"- female beneficiary, Malaoangeng CC, Leribe District. }\end{array}$ \\
\hline $\begin{array}{l}\text { Malawi } \\
\text { SCT }\end{array}$ & $\begin{array}{l}\text { "When people talk ill of us because of the CT we simply block our ears" - female beneficiary, Khonthi, } \\
\text { Salima District. } \\
\text { "Luck comes to a select few people at a time" - female non-beneficiary, Khonthi, Salima District. }\end{array}$ \\
\hline $\begin{array}{l}\text { Zimbabwe } \\
\text { HSCTP }\end{array}$ & $\begin{array}{l}\text { "Our relations with our neighbours are still the same but we become jealous when we see their children } \\
\text { wearing new shoes or clothes because we believe that we are just as poor and deserve the money" - } \\
\text { female beneficiary, Malakeng CC, Mafeteng District. } \\
\text { "The beneficiaries are very poor and have nothing while looking after orphans, they have no cattle or } \\
\text { goats, or even indigenous chicken and most deserve to be receiving this [CT]" - female non-beneficiary, } \\
\text { Ward 11, Garamonzi District. } \\
\text { "When you are a CT beneficiary you can be included in other forms of support" - male beneficiary, } \\
\text { Ward } 32 \text {, Garamonzi District. } \\
\text { "Since the programme... [HSCT]... started I'm not able to join anything else" - male beneficiary, Ward } \\
7 \text {, Chivi District. } \\
\text { "People were upset in the village about how it was done but when it was understood they were satisfied" } \\
\text { - male non-beneficiary, Ward 21, Garamonzi District. } \\
\text { "People talk, they talk badly during the pay days. Sometimes tension gets so out of hand that they may } \\
\text { stop talking to each other. During this time the chief normally calls them and speaks to them. They } \\
\text { normally tell them they shouldn't blame the beneficiaries. They are told that the people who selected us } \\
\text { don't know us and that they selected us through a raffle. They shouldn't be upset with them and one day } \\
\text { it might be they who will be selected" - wife of chief, Malaoaneng CC, Leribe District. }\end{array}$ \\
\hline
\end{tabular}

Table 15: Community perceptions of CT beneficiaries, issues of jealousy

Nevertheless, while CT receipt facilitated social inclusion, beneficiaries remained excluded from community networks that also have economic functions. Typically, these were the most powerful networks to which poor people are excluded. An example from Ethiopia is illustrative: the research found a high degree of social connectedness, with community based networks of mutual aid and economic collaboration considered very important to beneficiaries (and non-beneficiaries) and widely 
relied upon for support and risk management. Traditional mechanisms included informal rotating savings groups (iqqub) and funeral or burial societies (iddir). Such mechanisms were based on principles of reciprocity and contribution; if a household could do neither they would be left out.

Female headed-households, for example, were not often able to avail of labour-in-kind offera before the CT as they could not supply food and drinks in exchange for agricultural labour. On the other hand it was also found that the poor, including beneficiaries will try to give to others, because they have "sympathy" (understanding). As a female beneficiary in Abi Adi explained "if I make some progress, I must share". While the CT has enhanced beneficiaries' ability to join some social networks (iqqub and offera) they were not been able to enter the most important network in their society, iddir, which represent an important source of support and risk-sharing mechanism. Some, presumably better off, beneficiaries were already members of iddir and cash injections contributed to their membership. However, no beneficiary reported being able to join, the joining fee (e.g. 600 ETB [US\$30.45] in Abi Adi) was a significant barrier to access by the poor.

Although the example is specific to Ethiopia, in general the CT did not enable beneficiaries to be included in community-level decision-making processes or powerful social networks. This reflects a broader picture regarding livelihood gains from the CT because these networks can confer access to economic opportunities, such as access to a livelihoods project in a village.

\section{(c) Participation in Informal Savings and Credit Schemes}

Across communities, the CTs did not evenly increase participation in formal or informal savings schemes that can be important for livelihoods investment, risk reduction and investment in children's education. CT amounts are commonly insufficient to enable membership and the presence of savings groups varied. Although good evidence of joining groups was found (Table 16), exclusion and drop 
out were also noted, often because of the infrequency of CT payments and their relatively low value.

Non-participation in formal credit and savings mechanisms also arose where they are regarded with suspicion e.g. in Kenya.

\begin{tabular}{|l|l|}
\hline $\begin{array}{l}\text { Country \& } \\
\text { Programme }\end{array}$ & Examples of beneficiary and non-beneficiary perspectives from FGD and KII \\
\hline $\begin{array}{l}\text { Ghana } \\
\text { LEAP }\end{array}$ & $\begin{array}{l}\text { Men tended to participate more in livelihood-based or labour groups that shared ideas and farming } \\
\text { implements, while women participated in savings-based (susu) groups, which required regular } \\
\text { contributions. These networks were often fragile, however, and a lack of trust to pay fees and the } \\
\text { necessary dues for these groups was one reason why groups might dissolve and then reform. } \\
\text { Beneficiaries, despite their new income stream, could not automatically gain (re)-entry to these economic } \\
\text { groups. They could still be excluded if they were considered a liability, either because they were too } \\
\text { physically frail (particularly male labour groups) or were seen to be a risk with regard to regular } \\
\text { contributions. }\end{array}$ \\
\hline
\end{tabular}




\begin{tabular}{|c|c|}
\hline & $\begin{array}{l}\text { "We won't let them [the most physically frail] join us because they will be asking too much of us and } \\
\text { yet they don't bring anything to the table" - male non-beneficiary, Northern Region. } \\
\text { "If they know that you are risky...they will be hesitant towards you... you will be the last person to } \\
\text { access credit" - female beneficiary, Central Region. }\end{array}$ \\
\hline $\begin{array}{l}\text { Kenya CT- } \\
\text { OVC }\end{array}$ & $\begin{array}{l}\text { In the Kenyan communities there were many 'merry-go-round' savings schemes. It was found that the } \\
\text { CT enabled household heads to participate in these contribution-based networks. For female } \\
\text { beneficiaries in particular this meant an increased ability to contribute regularly and reliably. E.g. an } \\
\text { elderly female widow looking after three orphaned grandchildren had been able to join a merry-go-round } \\
\text { for one year, contributing KSh } 300 \text { (US\$ } 1.90 \text { ) every two weeks in order to raise money for the orphans } \\
\text { in her care. For male beneficiaries the CT enabled them to contribute more reliably - and be perceived } \\
\text { as more reliable - to funeral associations. } \\
\text { Savings were used for school or health costs, investment in farm inputs, livestock purchases, and } \\
\text { livelihood diversification. These 'merry-go-round' savings schemes were encouraged by beneficiary } \\
\text { committees; indeed some beneficiaries understood them to be compulsory. }\end{array}$ \\
\hline $\begin{array}{l}\text { Ethiopia } \\
\text { SCTPP }\end{array}$ & $\begin{array}{l}\text { In both Hintalo Wajirat and Abi Adi, the study found that regular cash injections enabled some } \\
\text { beneficiaries to save, either through a savings account or informally in their homes. } \\
\text { Iqqub are short-lived rotating funds governed by oral by-laws and based on norms of trust and } \\
\text { reciprocity. In Sebebera a number of female beneficiaries joined local iqqub, took out loans and } \\
\text { purchased livestock as precautionary savings in the face of shocks such as drought or emergencies such } \\
\text { as illnesses. }\end{array}$ \\
\hline $\begin{array}{l}\text { Lesotho } \\
\text { CGP }\end{array}$ & $\begin{array}{l}\text { "Nobody wants to lend money to the poor because they cannot afford to pay people back, what people } \\
\text { usually do is help poor people without expecting anything in return, but they are only being helped in } \\
\text { kind. When it is done in cash, people usually expect them to do piecemeal jobs for them such as doing } \\
\text { the laundry" - chief, Litjotjela CC, Leribe District. } \\
\text { "Neighbours are now able to lend to us because they know we are now able to pay them back" - female } \\
\text { beneficiary, Malakeng CC, Mafeteng District. }\end{array}$ \\
\hline $\begin{array}{l}\text { Malawi } \\
\text { SCT }\end{array}$ & $\begin{array}{l}\text { 'Village Savings and Loans' (VSL) schemes are increasing in popularity in Malawi. Research found } \\
\text { enormous variation of different schemes regarding permitted contributors and borrowers, level of } \\
\text { contribution and conditions of the loan. This was reflected in high variable experiences for CT } \\
\text { beneficiaries of contributing to and borrowing from VSL. Generally it was found that payment delays } \\
\text { created difficulties because members could no longer contribute. Also beneficiaries may borrow from a } \\
\text { VSL to compensate household income in the absence of the CT and this ran the risk of indebtedness due } \\
\text { to the accumulation of interest. }\end{array}$ \\
\hline $\begin{array}{l}\text { Zimbabwe } \\
\text { HSCTP }\end{array}$ & $\begin{array}{l}\text { "The amount of cash received does not allow us to contribute... [ to savings groups]... due to household } \\
\text { needs" - female beneficiary, Ward 7, Chivi District. } \\
\text { "Marrounds... [informal savings schemes]... are there but they are far from us at the moment, you try } \\
\text { to think of marrounds but you are also thinking of school fees and food"- female beneficiary, Ward 32, } \\
\text { Chivi District. }\end{array}$ \\
\hline
\end{tabular}

Table 16: Informal lending and beneficiary engagement with savings \& credit schemes

\section{CONCLUSIONS}

This article has examined the livelihood impacts of CTs in Africa through a cross-case qualitative study of six CT programmes in six countries. As a modality for social protection, CT programmes are reaching a growing number of people across the Continent, with impact evaluations providing learning

to improve social welfare and wider outcomes. By bringing beneficiary perspectives into view, our 
study contributes to this learning by encompassing the insights of the poor and giving due recognition to their priorities.

The analysis and insights of poor beneficiaries give powerful expression to lived experiences of poverty, as conveyed in quotes presented in the article. These voices starkly capture how the strategic livelihood choices beneficiaries are able to make have to be situated within the context of severe deprivation within beneficiary households. Food, cleanliness, clothing, shelter and medicine are prioritised, as are payments for children's education. Beneficiaries also highly valued their ability to make cash contributions to social and religious funds spending that conferred self-respect, dignity, hope and inclusion.

The 161 FGDs conducted across 36 communities highlighted both subtle and more marked differences in vulnerability between beneficiaries. Typically, this related to whether beneficiaries were ablebodied and healthy, or whether they were elderly, sick or disabled, and to the number of dependents reliant upon them. The rapid nature of research in each community presented a 'snapshot view', but still data highlighted temporality in terms of the dynamic nature of this vulnerability, particularly in terms of seasonally related shocks, hunger and illness. As a result, different priorities for CT expenditure come into play at different times. For some households, the full amount of the CT is spent on meeting welfare needs and school costs throughout the year, whereas for others and at certain times of year, there is small leeway for livelihoods-related expenditure. This variation is to be anticipated when the target group includes labour constrained households, as in the case of the Ethiopia SCTPP, the Ghana LEAP, the Malawi SCT, and the Zimbabwe HSCTP.

Against this background, the data nevertheless demonstrates positive marginal livelihood impacts from the CT. Focusing on the household economy, the research confirmed the first hypothesis in finding 
that a small amount of cash improved strategic livelihood choices. This included positive change to beneficiary capability for making such choices (through greater dignity, wellbeing, self-respect, inclusion, etc.) and in the livelihood activities beneficiary households carry out, shifting from deleterious coping strategies such as child labour and begging, and making small differences to labour allocation decisions. In the long-term, priority given to investment in children's education also has potential to lead to positive livelihood outcomes. The transfer was less uniformly effective at increasing productive investments. Many vulnerable beneficiary households continued to rely on the cash as a safety net to meet daily needs, including child welfare and education, and did not have surplus to spend on assets. The impact of the CT on livelihood choices and asset investment had gender dimensions, although impacts varied according to social norms and culture. Typically, women could make small changes in the labour they carried out, although not in their workload overall (except reduction in work for some elderly women). However, an overarching finding was lack of CT impact upon existing patriarchal norms regarding women's labour, their role in economic decision-making at household level, and their ability to invest in productive assets.

Focusing on social networks, the second and third hypotheses were partially confirmed. CTs generally did improve beneficiaries' access to economic collaboration to support livelihood impact. This was strongly linked to the regularity and certainty of the CT payment, however, and collaboration tended to occur when expenditure for basic needs or school costs was least pressing. Inclusion in new economic networks was rare, and was more likely to occur between fellow beneficiaries and extended family networks. In addition, CTs increased the ability of the poorest and most vulnerable to "re-enter" the social life of their extended families and communities, decreasing the social distance between the poorest households in the community and local institutions and strengthening overall connectedness. There was, however, no evidence that CTs significantly improved beneficiaries' inclusion in community-level decision-making processes or the most powerful networks that could give access to 
opportunities, such as involvement in a livelihoods project. Active participation in decision-making remained particularly difficult for elderly, immobile or illiterate beneficiaries.

Evidence comparing CT impact on beneficiary livelihoods within and between countries brought to the fore a range of factors that mediate livelihood impact at household level. These factors include the significance of wider economic opportunities for livelihood outcomes, which extended to the livelihoods afforded by agro-ecological conditions, as well as climate change related trends in droughts and water availability. In rural communities, differences in levels of access to labour and land for additional crops were also major factors in determining levels of strategic investment of CT income in agricultural production. Diversification beyond agricultural livelihoods into trading or service provision was strongly determined by the underpinning strength of the market economy and level of spending power within and beyond the community.

The study pointed to operational findings that are also highly relevant for promoting beneficial livelihood impacts. Perhaps of greatest importance was beneficiaries' need for regular and predictable payments. Irregularity - present across all programmes except the Ethiopia SCTPP - had a profoundly negative impact on both welfare and the livelihood strategies of beneficiaries, threatening achievements, undermining social safety net functions, jeopardizing children's school attendance, and threatening economic initiatives. There was ample evidence that late payments can worsen household economic security and prompt recourse to negative risk-coping mechanisms. In short, if CT income flows are predictable and regular (as programme design intends), the livelihoods benefit could be greater.

Our research involved rapid participatory data collection based on a robust and replicable methodology and sampling protocol. This has elicited a view of CT impact on beneficiary livelihoods whose value 
is depth of insight across different programmes, communities and contexts. The short periods of data collection were, however, also a limitation of the study, sacrificing greater depth and triangulation of findings over a longer period of time and with a greater range of actors. There is an opportunity for future research to better integrate this type of rapid qualitative study within longitudinal 'large-N' datasets in order to provide and interpret evidence on whether livelihood impacts are sustained after beneficiaries graduate from CT programmes and on the long-term economic outcomes of investment in children's education. An important element of such future integrated studies will be to situate findings in an understanding of the political economic context, including the influence of economic growth and distribution of opportunity on social wellbeing and equity.

\section{REFERENCES}

Adato, M., \& Hoddinott, J. (Eds.) (2010). Conditional Cash Transfers in Latin America.

Washington, DC: IFPRI.

Ardington, C., Case, A., \& Hosegood, V. (2009). Labor Supply Responses to Large Social Transfers: Longitudinal Evidence from South Africa. American Economic Journal: Applied Economics, 1(1), 22-48. DOI: 10.1257/app.1.1.22 
Arnold, C. with Conway, T. \& Greenslade, M. (2011). Cash Transfers Evidence Paper. London: DFID.

Asfaw, S., Davis, B., Dewbre, J., Handa, S., \& Winters, P. (2014). Cash Transfer Programme, Productive Activities and Labour Supply: Evidence from a Randomised Experiment in Kenya. The Journal of Development Studies, 50(8), 1172-1196. DOI: 10.1080/00220388.2014.919383

Baird, S., Ferreira, F.H.G., Özler, B. (2013) Relative Effectiveness of Conditional and Unconditional Cash Transfers for Schooling Outcomes in Developing Countries: A Systematic Review. Retrieved from: https://media.proquest.com/media/pq/classic/doc/3987746011 Accessed: March 26, 2017.

Ballard, R. (2013). Geographies of Development II: Cash Transfers and the Reinvention of Development for the Poor, Progress in Human Geography, 37, 811-21. DOI: $10.1177 / 0309132512474739$

Barca, V., Brook, S., Holland, J., Otulana, M., \& Pozarny, P. (2015). Qualitative Research and Analyses of the Economic Impacts of Cash Transfer Programmes in sub-Saharan Africa: Synthesis Report. Rome: FAO. http://www.fao.org/economic/ptop/publications/reports/en/ Accessed: December 2, 2016

Barrientos, A. (2012). Social Transfers and Growth: What Do We Know? What Do We Need to Find Out? World Development 40(1), 11-20. DOI:10.1016/j.worlddev.2011.05.012

Boone, R., Covarrubias, K., Davis, B., \& Winters, P. (2013). Cash Transfer Programs and Agricultural Production: The Case of Malawi. Agricultural Economics, 44, 365-378. DOI: 10.1111/agec. 12017

Bosworth, J. Alvar, C., Corral, L., Davis, B., Musembi, D., Mwasiaji, W., Ochieng, S., Pearson, R., Pozarny, P., Ward, P., Wiseman, W. (2016) The Cash Transfer Programme for Orphans and Vulnerable Children: The Catalyst for Cash Transfers in Kenya, in Davis, B., Handa, S., Hypher, N., Winder Rossi, N., Winters, P., Yablonski, J. (eds.) (2016) From Evidence to Action: The Story of 
Cash Transfers and Impact Evaluation in Sub-Saharan Africa (pp. 117 - 145). Oxford: FAO, UNICEF, Oxford University Press.

Bureau of Labour and Social Affairs Tigray, Ethiopia [BOLSA Tigray] (2011). Manual of Operations for the Tigray Social Cash Transfer Pilot Program, 2011-2014. Tigray BOLSA/UNICEF. Caeyers, B. \& Dercon, S. (2012). Political Connections and Social Networks in Targeted Transfer Programs: Evidence from Rural Ethiopia. Economic Development and Cultural Change 60(4), 639675. DOI: $10.1086 / 665602$

Chambers, R. (1997). Whose Reality Counts? Putting the Last First. London: Intermediate Technology Publications.

Chambers, R. (1983). Rural Development: Putting the Last First. Harlow: Longman.

Chambers, R. \& Conway, R. (1991). Sustainable Rural Livelihoods: Practical Concepts for the $21^{\text {st }}$ Century. Retrieved from: http://www.ids.ac.uk/files/Dp296.pdf Accessed: 7, December 2016 Cornwall, A. (2007) Of Choice, Change and Contingency: 'Career Strategies' and Tactics for Survival Among Yoruba Women Traders. Social Anthropology 15(1), 27-46. DOI:10.1111/j.09640282.2007.00007.x

Covarrubias, K., Davis, B., \& Winters, P. (2012) From Protection to Production: Productive Impacts of the Malawi Social Cash Transfer Scheme. Journal of Development Effectiveness, 4(1), 50-77. DOI:10.1080/19439342.2011.641995

Daidone, S., Davis, B., Dewbre, J. \& Covarrubias, K. (2014a) Lesotho Child Grants Programme: 24month impact report on productive activities and labour allocation. Rome: FAO. Retrieved from http://www.fao.org/economic/ptop/publications/reports/en/ Accessed: December 2, 2016 Daidone, S., Davis, B., Dewbre, J., Gonzalez-Flores, M., Handa, S., Seidenfeld, D. \& Tembo, G. (2014b) Zambia's Child Grant Programme: 24-month impact report on productive activities and 
labour allocation. Rome: FAO. Retrieved from

http://www.fao.org/economic/ptop/publications/reports/en/ Accessed: December 2, 2016

Davis, B., Handa, S., Hypher, N., Winder Rossi, N., Winters, P., Yablonski, J. (Eds.) (2016) From

Evidence to Action: The Story of Cash Transfers and Impact Evaluation in Sub-Saharan Africa.

Oxford: FAO, UNICEF, Oxford University Press.

Davis, B., Handa, S., Hypher, N., Winder Rossi, N., Winters, P., \& Yablonski, J. (2016a) The

Transfer Project, Cash Transfers, and Impact Evaluation in Sub-Saharan Africa, in Davis et al. (Eds.)

From Evidence to Action: The Story of Cash Transfers and Impact Evaluation in Sub-Saharan Africa

(pp. 1-16). Oxford: FAO, UNICEF, Oxford University Press.

Davis, B., Handa, S., Hypher, N., Winder Rossi, N., Winters, P., \& Yablonski, J. (2016b)

Conclusions and Policy Implications for Cash Transfer Programmes, in Davis et al. (Eds.) From

Evidence to Action: The Story of Cash Transfers and Impact Evaluation in Sub-Saharan Africa (pp.

335-358). Oxford: FAO, UNICEF, Oxford University Press.

Davies, S. \& Davey, J. (2008). A Regional Multiplier Approach to Estimating the Impact of Cash Transfers on the Market: The Case of Cash Transfers in Rural Malawi, Development Policy Review, 26(1), 91-111. DOI: 10.1111/j.1467-7679.2008.00400.x

De Sardan, J-P., Hamani, O., Issaley, N., Adamou, H., \& Oumaron, I. (2014). Les Transferts Monétaires au Niger: le grand malentendu, Revue Tiers Monde 2, 107-130.

DOI:10.3917/rtm.218.0107

De Sardan, J-P. (2014). La manne, les normes et les soupçons: Les contradictions de l'aide vue d'en bas. Revue Tiers Monde 3, 197-215. DOI:10.3917/rtm.219.0197

Ellis, F. (2012) 'We Are All Poor Here': Economic Difference, Social Divisiveness and Targeting Cash Transfers in Sub-Saharan Africa. The Journal of Development Studies 48(2): 201-4. DOI:

$10.1080 / 00220388.2011 .625408$ 
Ferguson, J. (2015). Give a Man a Fish: Reflections on the New Politics of Distribution. Durham: Duke University Press.

Fisher, E., Pozarny, P., Estruch, E. (2016). Qualitative Research on Decent Rural Employment: Malawi Case Study. FAO: Rome.

Fiszbein, A., Shady, N., with Ferreira, F.H.G., Grosh, M., Keleher, N., Olinto, P., \& Skoufias, E. (2009). Conditional Cash Transfers: Reducing Present and Future Poverty. Washington, DC: World Bank.

Garcia, M. \& Moore, C.M.T. (2012). The Cash Dividend: The Rise of Cash Transfer Programmes in Sub-Saharan Africa. Washington, DC: World Bank.

Gilligan, D.O., Hoddinot, J., \& Taffesse, A.S. (2008). The Impact of Ethiopia's Productive Safety Net Programme and its Linkages. DP00839. IFPRI: Washington.

Hanlon, J. Barrientos, A. \& Hulme, D. (2010). Just Give Money to the Poor: The Development Revolution in the Global South. Danvers, MA: Kumarian Press.

Holland, J., Attah, R., Barca, V., O’Brien, C., Brook, S., Fisher, E., Kardan, A. (forthcoming, 2017). Getting the Most out of Mixed Methods: Reflections from a Multi-Country Cash Transfer Impact Assessment, Centre for Development Impact, Practice Paper.

Kagin, J., Taylor, J.E., Alfani, F. \& Davis, B. (2014). Local Economy-wide Impact Evaluation of Ethiopia’s Social Cash Transfer Pilot Programme. FAO: Rome. Retrieved from: http://www.fao.org/economic/ptop/publications/reports/en/ Accessed: December 2, 2016 MacAuslan, I. \& Rieman-Schneider, N. (2011). Richer but Resented: What do Cash Transfers do to Social Relations and Does it Matter? IDS Bulletin 42(6): pp. 60-66. DOI: 10.1111/j.17595436.2011.00274.x 
Miller, C. \& Tsoka, M. (2012). Cash Transfers and Children's Education and Labour Among

Malawi’s Poor. Development Policy Review 30(4): 466-522. DOI: 10.1111/j.1467-

7679.2012.00586.x

Miller, C., Tsoka, M., Reichert, K., \& Hussaini, A. (2010). Interrupting the Intergenerational Cycle of Poverty with the Malawi Social Cash Transfer. Vulnerable Children and Youth Studies, 5(2): 108121. DOI:10.1080/17450120903499452

Niño-Zarazúa, M. Barrientos, A. Hickey, S. \& Hulme, D. (2011). Social Protection in Sub-Saharan Africa: Getting the Politics Right, World Development 40(1): pp. 163-176. DOI:

10.1016/j.worlddev.2011.04.004

Oxford Policy Management [OPM] (2014a). Qualitative Research and Analyses of the Economic Impacts of Cash Transfer Programmes in sub-Saharan Africa: Lesotho Country Case Study. FAO: Rome. Retrieved from: http://www.fao.org/economic/ptop/publications/reports/en/ Accessed: December 7, 2016

Oxford Policy Management [OPM] (2014b). Qualitative Research and Analyses of the Economic Impacts of Cash Transfer Programmes in sub-Saharan Africa: Malawi Country Case Study. FAO: Rome. Retrieved from: http://www.fao.org/economic/ptop/publications/reports/en/ Accessed:

December 7, 2016

Oxford Policy Management [OPM] (2014d) Qualitative Research and Analyses of the Economic Impacts of Cash Transfer Programmes in sub-Saharan Africa: Kenya Country Case Study. FAO: Rome. http://www.fao.org/economic/ptop/publications/reports/en/ Accessed: December, 72016 OPM (2014c) Qualitative Research and Analyses of the Economic Impacts of Cash Transfer Programmes in sub-Saharan Africa: Ethiopia Country Case Study. FAO: Rome. http://www.fao.org/economic/ptop/publications/reports/en/ Accessed: December 7, 2016 
Oxford Policy Management [OPM] (2013a). Qualitative Research and Analyses of the Economic Impacts of Cash Transfer Programmes in sub-Saharan Africa: Ghana Country Case Study. FAO: Rome. Retrieved from: http://www.fao.org/economic/ptop/publications/reports/en/ Accessed: December 7, 2016

Oxford Policy Management [OPM] (2013b). Qualitative Research and Analyses of the Economic Impacts of Cash Transfer Programmes in sub-Saharan Africa: Zimbabwe Country Case Study. FAO: Rome. Retrieved from: http://www.fao.org/economic/ptop/publications/reports/en/ Accessed: December 7, 2016

Oxford Policy Management [OPM] (2012). Research Guide: Qualitative Research on the Economic Impacts of Cash Transfer Programmes in Sub-Saharan Africa. http://www.fao.org/economic/ptop/publications/reports/en/ Accessed: December 7, 2016 Pearson, R., Afaw, S., Baschieri, A., Birru, B., Berhane, G., Chaiban, T., Davis, B., Devereux, S., Hoel, J., Kagin, J., Ledlie, N., Heshe, L., Mahonde, D., Pigois, R., Pozarny, P., Roelen, K., Schwab, B., Salama, P., Sessay, I., Tegebu, F.N., Tsegay, Y., \& Webb, D. (2016). The Role of the Tigray Pilot Social Cash Transfer Programme and its Evaluation in the Evolution of the Tigray Social Protection Policy, in Davis et al. (Eds.) From Evidence to Action: The Story of Cash Transfers and Impact Evaluation in Sub-Saharan Africa (pp. 146-167). Oxford: FAO, UNICEF, Oxford University Press.

Pellerano, L., Daidone, S., Davis, B., Farooq, M., Homayoun, M., Kardan, A., Masasa, M., Ousmane, N., Ramirez, B., \& Safi, N. (2016). Does Evidence Matter? Role of the Child Grant Programme in the Consolidation of Social Protection Sector in Lesotho, in Davis, et al. (eds.) From Evidence to Action: The Story of Cash Transfers and Impact Evaluation in Sub-Saharan Africa (pp. 247-280). Oxford: FAO, UNICEF, Oxford University Press. 
Pozarny, P. \& Barrington, C. Qualitative Methods in Impact Evaluations in Cash Transfer Programmes in the Transfer Project in Sub-Saharan Africa, in Davis, et al. (eds.) From Evidence to Action: The Story of Cash Transfers and Impact Evaluation in Sub-Saharan Africa (pp. 71-93). Oxford: FAO, UNICEF, Oxford University Press.

Robertson, L., Mushati, P., Skovdal, M., Eaton, J.W., Makoni, J.C., Crea, T., Mavise, G., Lovemore, D., Schumacher, C., Sherr, L., Nyamukapa, C., Gregson, S. (2013) Involving Communities in the Targeting of Cash Transfer Programs for Vulnerable Children: Opportunities and Challenges, World Development 54, 325-337. DOI: 10.1016/j.worlddev.2013.09.002.

Rodríguez-Oreggia, E. \& Frieiji, S. (2012). Long-term Impact of a Cash-Transfers Programme on the Labor Outcomes of Rural Youth in Mexico. CID Working Paper: Harvard University. Retrieved from: http://growthlab.cid.harvard.edu/files/growthlab/files/230.pdf Accessed: March 26, 2017.

Roelen, K. \& Devereux, S. (2013). Promoting Inclusive Social Protection in the Post-2015 Framework, IDS Policy Briefing 39.

Samuels, F. \& Jones, N. (2013). Holding Cash Transfers to Account: Beneficiary and Community Perspectives. ODI: London. Retrieved from: http://www.odi.org/sites/odi.org.uk/files/odiassets/publications-opinion-files/8372.pdf Accessed: December 7, 2016

Scoones, I. (2009). Livelihoods perspectives and rural development. The Journal of Peasant Studies 36(1): 171-196. DOI: 10.1080/03066150902820503

Seidenfield, D., Dumba, L., Handa S., Muwoni L., Reeves H., Sammon, E. (2016) Zimbabwe: Using Evidence to Overcome Political and Economic Challenges to Starting a National Unconditional Cash Transfer Programme, in Davis et al. (Eds.) From Evidence to Action: The Story of Cash Transfers and Impact Evaluation in Sub-Saharan Africa (pp. 226-246). Oxford: FAO, UNICEF, Oxford University Press. 
Sen, A. (1997). Editorial: Human Capital and Human Capability, World Development 25(12): pp.1959-1961.PII: S0305-750X (97)10014-6.

Singh, I., Squire, L. \& Strauss, J. (Eds.) (1986). Agricultural Household Models: Extension, Application and Policy. Baltimore, MD: John Hopkins University Press.

Taylor, J.E., Thome, K. and Filipski, M. (2016) Local Economy-Wide Impact Evaluation of Social Cash Transfer Programmes, in Davies et al. (Eds.) From Evidence to Action: The Story of Cash Transfers and Impact Evaluation in Sub-Saharan Africa (pp. 94-116). Oxford: FAO, UNICEF, Oxford University Press.

Thome, K., Taylor, J.E., Tsoka, M., Mvula, P., Davis, B. and Handa, S., (2015) Local Economywide Impact Evaluation (LEWIE) of Malawi's Social Cash Transfer (CT) Programme. Rome: FAO. Retrieved from: http://www.fao.org/economic/ptop/publications/reports/en/ Accessed: December 7, 2016

Thome, K., Taylor, JE., Davis, B., Handa, S., Seidenfeld, D., \& Tembo, G. (2014). Local Economywide Impact Evaluation (LEWIE) of Zambia's Child Grant Programme. Rome: FAO and the World Bank. Retrieved from: http://www.fao.org/economic/ptop/publications/reports/en/ Accessed: December 7, 2016

Tirivayi, N., Knowles, M., \& Davis, B. (2013). The Interaction between Social Protection and Agriculture: A Review of the Evidence. Rome: FAO. Retrieved from: http://www.fao.org/economic/ptop/publications/reports/en/ Accessed: December 7, 2016 Wallace, T. \& Chapman, J. (2011). Walking the Talk: Cash Transfers and Gender Dynamics. Oxford: Oxfam and Concern Worldwide.

World Bank (2014). The State of Social Safety Nets 2014. Washington DC: World Bank. 


\section{Endnotes}

${ }^{1}$ The views expressed in this article are those of the authors; they do not necessarily reflect the position of any organisation linked to the study.

${ }^{2}$ Definitions of 'labour constrained' vary by CT programme, however broadly this refers to households with no adults who are 'fit for work' or whose youth attend school or college and are not available to work, and/or that have high dependency ratios.

${ }^{3}$ For details of the PtP project and its outputs see: URL http://www.fao.org/economic/ptop/home/en/ Accessed February 1, 2016. The qualitative case study reports, synthesis and practice paper are Barca, Brook, Holland, Otulana, \& Pozarny, 2015; OPM a/b (2013); OPM a/b/c/d (2014); and, Holland et al. (forthcoming). See also Pozarny and Barrington (2016).

${ }^{4}$ Examples of conditions include making receipt of the CT conditional on visits to health clinic or school attendance. 'Conditional' CT programmes are a norm in Latin America whereas in Africa CTs tend to be given to beneficiaries without conditions attached, or with limited conditions and weak enforcement and monitoring.

${ }^{5}$ This notion of capability follows Chambers (1997, p.241) sense of 'the quality of being capable', rather than the more complex concept proposed by Sen (1997).

${ }^{6}$ For the study overall, five hypotheses were examined, including on the local economy and operational aspects of CT programmes (OPM a/b, 2013; OPM a/b/c/d, 2014).

${ }^{7}$ The length of time individuals / households were enrolled in the programme varied - individually, between districts, and between countries; as did programme policies and policy implementation regarding beneficiary exit strategies. To evaluate productive impact of the $\mathrm{CT}$, the research sampling strategy deliberately chose districts / localities where beneficiaries had been CT recipients for a significant period; as a rule of thumb the CT had been received by respondents (beneficiaries) for 3 years or more.

${ }^{8}$ Targeting differences were not only apparent between programmes but also existed related to targeting between localities within single country programmes e.g. where there were modifications to targeting criteria as the programme matured e.g. the CT-OVC in Kenya that incorporated an objectified mechanism for proxy means testing as it developed.

${ }^{9}$ As identified in Table 2, the names of the lower administrative units used for sampling purposes were: Ethiopia - tabia; Ghana - district; Kenya - location and sub-location; Lesotho - community council; Malawi - traditional authority and village cluster; Zimbabwe - ward.

${ }^{10}$ A detailed livelihoods profile of each study location can be found in the country case study reports: OPM a/b (2013); OPM a/b/c/d (2014). 
${ }^{11}$ This is much higher than an estimated 20 percent of household income found to be the case in quantitative studies e.g. Boone et al. (2013), Asfaw et al. (2012), Covarrubias et al. (2012).

${ }^{12}$ This was accounted for by lack of objective mechanism to differentiate the poverty level of eligible households, creating small but significant inclusion error coupled with weak graduation strategies (see Bosworth et al., 2016: 126). Owendo district (previously Migori) was an early entry to the CT-OVC programme, proxy means testing was later introduced including in Machokos district. Personal communications: Monitoring and Evaluation Co-ordinator, Department of Children's Services, Ministry of Gender, Children and Social Development, Nairobi July 23, 2012; and Migori District Children Officer July 18, 2012.

${ }^{13}$ The CWA tool incorporated wealth ranking and local perceptions of wealth, poverty, wellbeing and ill-being. Typically, respondents identified four categories with local characteristics for deprivation: 'wealthy' (or relatively better off), 'the middle', 'the poor' and 'the very poor'. Generally 'the poor' equated to extreme poor (US\$1.25 per day) and 'the very poor' to severe poor (US\$0.70 per day) (ODI, 2014). 'The middle' included professionals such as teachers, but also those who fluctuated between middle and poor. Wellbeing categories are community-specific, therefore we deliberately use the loose term of 'marginally better off' to capture differences between CT recipients who were 'very poor' and those who were 'poor' or, less commonly, 'middle'.

${ }^{14}$ Elderly female beneficiary, Phalombe District.

${ }^{15}$ Female non-beneficiary, Ward 32, Chivi district, Zimbabwe.

${ }^{16}$ Research on social protection and rural employment in Malawi (Fisher et al., 2016) found different perceptions amongst the youth who farm because it is amongst the few options open to them, not a preferential activity. Our study did not examine youth perceptions.

${ }^{17}$ These results correspond to findings from quantitative impact evaluations, where some impact was seen on purchase of assets and inputs but not systematically within or across countries (OPM, 2014c; Asfaw et al. 2014; Covarrubias et al., 2012).

${ }^{18}$ For examples see: Ellis (2012), MacAuslan \& Rieman-Schneider (2011), and Robertson et al. (2011). 